\title{
Ceza ve İnfaz Kurumlarında Açlık Grevine Müdahale, Hukuka Uygunluk Nedenleri ve AïHM Yaklaşımı
}

Av. Dr. Recep DOĞAN*

Makalenin Geliş Tarihi: 27.04.2021 Kabul Tarihi: 26.07.2021

Bu makale hakem incelemesinden geçmiştir ve TÜBİTAK - ULAKBİM

Veri Tabanında indekslenmektedir.

DOI 10.30915/abd.978857

* Avukat,Ankara Barosu, Dr. LL.M.,PhD,Keele University UK.

https://orcid.org/0000-0002-7739-3071 


\section{CEZA VE INFAZ KURUMLARINDA AÇLIK GREVINE MÜDAHALE, HUKUKA UYGUNLUK NEDENLERI VE AIHM YAKLAŞIMI}

\section{öz}

$\mathrm{Bu}$ makalede, insan hakları perspektifinden açlık grevinin hukuki niteliği ile ceza ve infaz kuramlarında açlık grevine zor kullanılarak müdahale edilmesinin mümkün olup olmadığı ve ceza sorumluluğunu gerektiren haller Avrupa İnsan Hakları Mahkemesi'nin yaşam hakkına ve açlık grevine müdahaleye ilişkin kararları ışığında tartışlacaktır. Bu bağlamda, açlık grevine hangi hallerde müdahale edilebileceği, hangi hallerde sınırın aşılmış sayılması gerektiği hukuka uygunluk sebepleri açısından ele alınıp incelenecek, uygulanabilecek hukuka uygunluk nedeninin maddi ve şekli şartlarının sadece iç hukuka göre değil Avrupa İnsan Hakları Sözleşmesi (AİHS), Avrupa İnsan Hakları Mahkemesi (AİHM) kararları ve Dünya Hekimler Birliği'nin Açlık Grevlerine İlişkin Bildirgesi dikkate alınarak belirlenmesi gerektiği açıklanacaktır.

\section{Anahtar Kelimeler:}




\section{FORCE-FEEDING DURING THE HUNGER STRIKE IN PRISONS, DEFENCES TO CRIMINAL CULPABILITY AND THE ECHR CASE LAW \\ ABSTRACT}

From the human rights perspective, this article discusses the concept of hunger strike and explains whether it is possible to force-feed a prisoner who is on hunger strike against his/her wishes. In this context, the article investigates the lawfulness of the artificial feeding of a prisoner who is on hunger strike, the criminal culpability of those force-feeding a prisoner and available criminal defences, in the light of the European Court of Human Rights' (ECHR) case law on the right to life and hunger strikes in prisons. Then, the article argues that the issue of the artificial feeding of a hunger striker and the criminal or legal responsibility of those force-feeding a prisoner is a matter that cannot be decided or interpreted entirely based on the domestic law. The management of hunger strikes in prisons and the issue of artificial feeding should be decided by interpreting domestic law together with European Convention on Human Rights, the case law of the ECHR and World Medical Association Declaration on Hunger Strikers.

\section{Keywords:}

Hunger Strike

The Right To Life

Force-Feeding

Defences To Criminal Culpability

The ECHR Case Law On Hunger Strike In Prisons 


\section{GíRiş}

Açlık grevi, fiil ehliyetine sahip bir kimsenin kendi hür iradesiyle bilinçli olarak belirli bir zaman dilimi için yiyecek ve/veya sıvı almayı reddetmesi şeklinde uygulanan bir protesto biçimidir. Açlık grevi ölümle sonuçlanabilecek olmasına rağmen temel amaç ölüm değildir. Dolayısıyla açlık grevi bir intihar biçimi değildir. ${ }^{[1]}$ Açlık grevine müdahalenin mümkün olup olmadığ 1 ve ceza sorumluluğunun doğup doğmayacağ 1 hususu ise tıp, hukuk ve tıp etiği gibi birden çok bilim dalının alanına giren karmaşık birçok sorunun cevaplandırılmasını gerekli kılmaktadır. Nitekim açlık grevine müdahale halinde, müdahalede bulunanların ceza sorumluluğunun olup olmadığının belirlenebilmesi için öncelikle açlık grevinin hukuki niteliğinin belirlenmesi, açlık grevinin bir hakkın veya özgürlüğün kullanılmasından ibaret olup olmadığı ve bu hakkın sınırlarının açıklanması gerekmektedir. Eğer açlık grevi bir hak ise daha yüksek bir değerin ya da çıkarın korunması adına bu hakkın kullanılması kısıtlanabilir mi? Bu kısıtlamanın sınırları ve usulü nelerdir? Kısıtlama halinde hangi hallerde ceza sorumluluğu doğar, hangi hallerde hukuka uygunluk nedeni söz konusudur? Bu soruların cevaplandırılması açlık grevinin öncelikle hukuki niteliğinin tam olarak ortaya konmasına bağlıdır.

Bu konuda yazılan eserlere bakıldığında, hukuki eserlerin gereğinden fazla ve bir dereceye kadar zorlama yorumlarla daha çok açlık grevine müdahalenin nasıl mümkün olabileceği konusuna yoğunlaştığ ${ }_{1}{ }^{[2]}$ tıbbi ve diğer eserlerin ise hangi hallerde eylemcinin iradesine saygı duyulmasının tıbbi etiğe uygun olduğu ve hekim için sorumluluk doğurmayacağı soru-

[1] Türk Tabipleri Birliği, "Açlık Grevleri Sırasında Tıbbi Etik İlkeler ve Bunun Pratik Yansımaları” Erişim adresi: https://www.ttb.org.tr/aclik grev/index.html. Erişim tarihi: 30.03.2021. Kavrama ilişkin diğer tanımlar için bkz. Rıfat Murat Önok, "İnsan Hakları ve Türk Ceza Hukuku Açısından, İnfaz Kurumlan ve Tutukevlerindeki Açlık Grevlerine Müdahale Etme Yükümlülügü ve Bunun İhmalinden Doğan Sorumluluk", IKÜ Hukuk Fakültesi Dergisi, 2005, C. 4, S. 1-2, s.140-142; Seval Kılıç, "Açlık Grevi ve Açlık Grevine Müdahale", TipHD, 2012, S.2, s.84-86.

[2] Doğan Soyaslan, “Türk Hukuk Düzeni ve Açlık Grevi Yapanlara Müdahale Sorunu”, Yargıtay Dergisi, 1990, C. 16, S.3; Metin Feyzioğlu, "Açlık Grevi”, AÜHFD, 1993, C. 43, S. 1; Ömer Ömeroğlu, "Avrupa İnsan Hakları Mahkemesi Kararları Işığında; Hükümlü, Tutuklu Ve Gözaltındakilerin Açlık Grevi, Ölüm Orucu Ve Müdahale Sorunu", EÜHFD, 2011, C. XV, S. 3-4; Şahin Akıncı, "İrade Muhtariyeti İlkesi ve Şahsiyet Hakları Açısından Ötanazi, Açlık Grevi ve Ölüm Orucu”, Selçuk Üniversitesi Hukuk Fakültesi Dergisi, 1998, C.6, S.1-2, Prof. Süleyman Arslan’a Armağan. 
suna cevap aradığı görülmektedir. ${ }^{[3]}$ Yine, açlık grevinin hukuki niteliğinin belirlenmesine ilişkin tartışmalarda, açlık grevi hakkının ve ölme hakkının Anayasảda ve diğer hukuksal düzenlemelerde yer almadığı, bu nedenle hak arama hürriyeti kapsamında değerlendirilemeyeceği şeklinde konuyu tüm yönleriyle ele almayan, yüzeysel tartışmaların yapıldığ ${ }^{[4]}$ görülmektedir. Konuyu insan hakları perspektifinden tüm boyutlarıyla ele alan eserler ${ }^{[5]}$ ile açlık grevlerine müdahalenin yaşamın kutsallığı prensibinden hareketle meşrulaştırılmayacağım savunan eserler ${ }^{[6]}$ ise azınlıkta kalmaktadır.

Dolayısıyla bu makalede, öncelikle açlık grevinin insan hakları perspektifinden hukuki niteliği tartışlacak, açlık grevine hangi hallerde müdahale edilebileceği, hangi hallerde sınırın aşılmış sayılması gerektiği, hukuka uygunluk nedenleri açısından ele alınıp incelenecektir. Ardından iç hukuktaki tüm bu tartışmaların, AİHM ${ }^{[7]}$ 'in yaşam ve ölüm hakkı ile açlık grevlerine müdahaleye ilişkin içtihatlarıyla ${ }^{[8]}$ uyumlu olup olmadığı açıklanacaktır. Makalede genel olarak ceza infaz kurumları ve tutukevlerinde açlık grevi yapan hükümlü ve tutuklulara müdahale konusu ele alınacaktır. Ancak, aksi açıkça anlaşılmadığı veya belirtilmediği sürece bu makale kap-

[3] Ata Soyer, "Açlık Grevleri/Ölüm Oruçları, TTB ve Son Tartışmalar”, Türk Tabipleri Birliği Toplum ve Hekim Dergisi, Kasım Aralık 2000, S.6; Bedia Boran, "Açlık Grevi/Ölüm Orucuna Müdahale Sorunu Tibbi ve Hukuki Yaklaşım”, Ankara Barosu Dergisi, 2007, Yıl. 65, S. 3; Eda Demirsoy Aşıkoğlu, "Kişi Dokunulmazlığı Hakkı Bağlamında Rıza Olmaksızın Yapılan Tıbbi Müdahaleler”, TAAD, 2018, Y.9, S.35.

[4] Ahmet Taşkın, "Açlık Grevleri ve Hak Arama Hürriyeti", AÜEHFD, 2003, C.VII, S.3-4.

[5] Önok; Murat Sevinç, "Bir İnsan Hakları Sorunu Olarak: Açlık Grevleri”, Ankara Üniversitesi SBF Dergisi, 2002, C. 57, S. 1.

[6] Mustafa Eren, "Ölüm Oruçları: Yaşamın Kutsallığı ve Direnme Hakkı İkileminde Bir Eylem Tarzı”, MSGSÜ Sosyal Bilimler Dergisi, 2017, C.1, S. 15.

[7] rine "İnsan Hakları Avrupa Sözleşmesi (İHAS)" şeklinde, Sözleşme hükümlerinin taraf devletlerce uygulanıp uygulanmadığını denetlemek üzere kurulan mahkemenin ise Türkçe’ye "Avrupa İnsan Hakları Mahkemesi (AİHM)” yerine "İnsan Hakları Avrupa Mahkemesi (İHAM)” şeklinde aktarılması gerektiği, yaygın kullanımın yanlış olduğu düşüncesi paylaşılmakla beraber, söz konusu terimlerin yaygın kullanım şekli bu makalede de tercih edilmiştir.

[8] Bu makale kapsamında, ele alınan tüm AİHM kararlarına AİHM veri bankası (https://hudoc.echr.coe.int) üzerinden ulaşılmış olup Türkçe kararlar için Adalet Bakanlığı İnsan Hakları Dairesi Başkanlığı tarafından çevirisi yapılan ve veri bankasında yer alan kararlardan faydalanılmıştır. Kullanılan bu Türkçe kararların künyesi makalede "Başvurucu / Türkiye" formatında belirtilmiş, diğer İngilizce kararların künyesi için ise "Applicant v." formatı kullanılmıştır. 
samında ileri süreceğimiz görüş ve açıklamalar hükümlü ve tutuklu olmayan kimseler için de geçerli olabilecektir.

\section{I- AÇLIK GREVININ INSAN HAKLARI PERSPEKTIFINDEN HUKUKI NITELIĞi}

\section{A. Açlık Grevi, Temel Hakların Vazgeçilmezliği ve Yaşamın Kutsallığı}

Şahsiyet haklarının Anayasa'nın 12/1. maddesi gereği dokunulmaz, devredilmez, vazgeçilmez temel haklardan olduğu, bunlardan vazgeçilmesinin mümkün olmadığı, bu nedenle beslenme hakkından ve devamında yaşam hakkından vazgeçmeye neden olacağı gerekçesiyle, açlık grevinin ve ölüm oruçlarının Anayasayla korunma alıına alınmadığı ve bu nedenle hukuka aykırı olduğu iddia edilmektedir. ${ }^{[9]}$ Vazgeçilemez hak ayrımı aslında doğal hukuk doktrinini ile ortaya çıkmış, daha sonra da 1776 Amerikan Bağımsızlık Bildirgesi'nde, 1789 Fransız İnsan ve Yurttaş Hakları Beyannamesi'nde hatta Anayasamız da dâhil olmak üzere birçok anayasa ve temel kanunda yer almıştır. Tüm bu düzenlemelerde ortak nokta, kişiye, başkalarına devredilemeyen, dokunulmaz, vazgeçilemez hakların bahşedilmiş olduğudur. Dolayısıyla kişinin kendisinin bile tasarrufta bulunamayacağı hakları bulunmaktadır. ${ }^{[10]}$

Bu iddianın geçerliliğini ele alalım. Örneğin, bir kimsenin ömür boyu hiç konuşmayacağı, düşüncesini ifade etmeyeceği veya ömür boyu evlenmeyip aile kurmayacağı hallerde de bir temel haktan vazgeçme söz konusudur. Bu durumda açlık grevi yaparak yaşam hakkından vazgeçmek mümkün değilse hiç evlenmemek suretiyle aile kurma hakkından, hiç konuşmamak suretiyle düşünceyi açılama ve yayma hürriyetinden vazgeçmek de mümkün olmamalıdır. Oysa hiçbir hukuk kuralı veya yorumu hiç evlenmeyen bir kimsenin zorla evlendirilmesi, hiç konuşmayan kimsenin

[9] Akınc1, s.737; Feyzioğlu, s.163; İzzet Özgenç, Türk Ceza Hukuku Genel Hükümler, 15. Bası, Seçkin, Ankara, 2019, s.376. Özgenç, açlık grevlerini ve ölüm orucu şeklindeki protesto eylemlerini bir "hak icrası" olarak görmenin mümkün olmadığını, ancak iradesi bu yönde oluşmuş olan kişilerin zorla beslenmesinin doğru ve hatta mümkün olmadığını, gerekli bilgilendirme ve ikna gayretlerinin sonuç vermemesi durumunda, gerekli beslenmeyi ihmal ederek ölen kişinin ölümünden herhangi bir kimsenin sorumlu tutulamayacağını belirtmektedir.

[10] Erika Biton Serdaroğlu, "Ötanazi-Ölme Hakkı", Marmara Üniversitesi Hukuk Fakültesi Hukuk Araştırmaları Dergisi, Cevdet Yavuz’a Armağan, 2016, C.22, S.3, s.484-485. 
zorla konuşturulması gerektiğini öngörmediği gibi bir kimseye "yemek yeme mükellefiyeti yükleyen” ${ }^{[11]}$ kural da yoktur.

$\mathrm{Bu}$ nedenle, temel bir haktan vazgeçmenin bizatihi kendisi kabul edilemez bir durum yaratıyor ve müdahaleyi gerektiriyor ise aile kurma hakkından veya düşünceyi ifade özgürlüğünden ömür boyu vazgeçen kimselere de temel bir haktan vazgeçtikleri için müdahale etmek gerekir. Ancak, aile kurma hakkından veya düşünceyi ifade özgürlüğünden ömür boyu vazgeçen kimsenin bu kararı, kendi sağlı̆̆ı ve vücut bütünlüğü üzerinde şu ana kadar bilinen olumsuz bir etki yaratmaz iken açlık grevi yaratmaktadır. Dolayısıyla meşruiyet açısından önemli olan husus, nitelik itibariyle hareketsiz kalmayı veya pasif bir durumu ifade eden vazgeçmenin kendisi değil vazgeçme nedeniyle ortaya çıkan yeni durumun kabul edilip edilemeyeceği, başka bir deyişle vazgeçmenin yaratabileceği yeni bir tehlike veya zarar riskinin göz önüne alınıp alınamayacağı noktasında kendini göstermektedir. Bu nedenle, kişinin bir temel haktan vazgeçmesinin meşru olup olmadığı, dolayısıyla bu vazgeçmeye karşı yapılacak müdahalenin meşru olup olmadığı, vazgeçmenin yaratabileceği muhtemel zarar tehlikesine göre belirlenmelidir.

Beslenme gibi bir temel haktan vazgeçme, kişinin vücut bütünlüğüne zarar verecek ise bu duruma müdahale edilmesi meşru görülebilir. Ancak bu düşünce biçimi de her zaman sorunun çözümüne katkı sağlamamaktadır. Örneğin ölümcül bir hastalığa yakalanmış kimsenin tedaviyi reddetmesi ve bu şekilde muhtemel yaşam süresini kısaltması halinde, ortaya çıkan yeni durum açlık grevi veya ölüm orucunda olduğu gibi vadesinden önce ölüm riski olduğuna göre, vadesinden önce ölüm durumu yaratan ötanazi ve tedaviyi reddetme imkânlarını da kabul etmemek, müdahale etmek gerekecektir. Oysa karşılaştırmalı hukuka bakıldığında, birçok ülkede ölümcül bir hastalığa sahip olanların tedaviyi reddetme hakkı olduğu gibi acı çekmeden gönüllü ölüm veya tıbbi destekli intihardan da yararlanabileceği kabul edilmektedir. ${ }^{[12]}$

Nitekim AİHM de aşağıda açıklanacağı üzere, insan hayatını üçüncü kişilerin müdahalesine karşı korumayı amaçlayan ve AİHS'in 2. maddesinde yer alan yaşam hakkının, ölme hakkını da verdiği şeklinde bir so-

[11] Akınc1, s.751.

[12] Serdaroğlu, s.470-479; Muharrem Özen/Meral Ekici Şahin, “Ötanazi”, Ankara Barosu Dergisi, 2010, Y.68, S. 4, s.21-24. 
nucun söz konusu maddenin yorumundan çıkarılamayacağını belirtmekle beraber, 2. maddenin herhangi bir kimsenin kendi hayatı ile ilgili olarak ne yapmayı tercih ettiği hususuyla ilgilenmediğini de belirtmektedir. Dolayısıyla, açlık grevinde bulunan kimsenin bir temel haktan vazgeçtiği ya da ölüm riski ile karşı karşıya kaldığı, bu nedenle eylemin meşru olmadığı, müdahale edilmesi gerektiği düşüncesi dayanaktan yoksun kalmaktadır.

Yine, açlık grevinin ölümle sonuçlanması ihtimali karşısında, yaşamın değerler sisteminde yer alan en üst değer olduğu, bu değerin her ne pahasına olursa olsun korunması gerektiği ifade edilmektedir. ${ }^{[13]}$ Bu düşünce biçimi, öncelikle hayatı anlamlı kılan ve değerler sisteminde en üst seviyeye çıkaran şeyin ne olduğu sorusunu sormamızı ve hayatın anlamını sorgulamamızı gerektirmektedir. Gerçekten de en üst değer olarak korunması gereken varlık olarak yaşam hakkı, hukuki açıdan en basit şekliyle doğumdan hemen sonra ölümden ise hemen önce varlığını sürdüren, nefes alıp verebilme yeteneğiyle kendisini ifade eden bir alana hitap etmekte ise de felsefi ve sosyal açıdan yaşamı anlamlı kılan şey, sadece nefes alıp vermek değildir. Yaşam sahip olunan değerler, ilkeler, prensipler ve fikirler ile anlamlı ve değerli hale gelmekte, sahip olunan sosyal rol, kimlik, bağlar ve etkileşim ile sosyal bir nitelik kazanmaktadır. Bireyin toplumun geri kalan kısmı ile etkileşim ve iletişimini zaman içerisinde yitirerek, toplumdaki rolünün, kimliğinin ve bağlantılarının tamamını veya neredeyse tamamını kaybettiği aşamada ise "sosyal ölüm" meydana gelmektedir. "Sosyal ölüm" halinde birey dış dünyadaki hayatın aktif bir üyesi olma konumunu yitirmekte, fiziki ve tıbbi olarak varlığını sürdürmesine rağmen toplumsal dışlama, ayrımcılığa tabi tutulma ya da kölelikte olduğu gibi tüm medeni haklardan mahrum bırakılma sebebiyle ölü muamelesi görmektedir. ${ }^{[14]}$

Dolayısıyla değerler sisteminde yaşamı en üst noktaya çıkaran şey, sosyal rol, kimlik ve bağlantılar ile anlamlı hale gelen ve etkileşim içinde bulunulan yaşamdır. İnsan sadece yaşam hakkına değil onurlu bir yaşam hakkına da sahiptir. Bu nedenle, açlık grevinde bulunan eylemci nefes alıp vermekten ibaret olan tıbbi ve hukuki alanda varlığı kabul edilen yaşa$\mathrm{m}$, sosyal ve felsefi alanda daha değerli ve onurlu bulduğu prensiplere ve ilkelere dayanan sosyal ve anlamlı yaşama erişmek için feda etmektedir. Tıpkı tutulduğu hastalık veya rahatsızlık sebebiyle yaşamını sosyal açıdan

[13] Akınc1, s.741; Feyzioğlu, s.163-164; Ömeroğlu, s.94-95.

[14] Jana Kràlovà, "What is social death?", Contemporary Social Science, 2015, C.10, S.3. 
değersiz ve anlamsız bulan kimsenin ölmeyi tercih etmesinde olduğu gibi eylemci de ölmeyi tercih etmektedir. Bu durum, "ölme hakkı veya erken ölümü tercih etme" gibi bir hakkın olup olmadığı sorusunu kendimize sormamıza, diğer yandan da kutsal olduğu belirtilen yaşam hakkının sadece nefes alıp vermekten ibaret olmadığının kabulü halinde intihar etme, açlık grevi, ölüm orucu ve ötanazi kavramları arasındaki farkın sandığımız kadar da çok olmadığı sonucuna ulaşmamıza neden olmaktadır.

Bu itibarla, intiharda hayattan umudunu kesmiş kişinin kendi isteğiyle hayatına son verdiği, gönüllü ölümde katlanılması imkânsız acıya son vermek için kişinin hayatına gönüllü olarak son verilmesini istediği, açlık grevinde ise "amacın politik olduğu, bir isteğe toplumun, kamuoyunun dikkatini çekmek amacıyla açlık grevinin yapıldığı" [15] iddiası, "yaşam hakkının 'kişinin hayatta kalma' hakkından ibaret olmadığı" ${ }^{[16]}$ düşüncesi kabul edildiğinde, anlamını ve önemini yitirmektedir. Bir başka deyişle, yaşam hakkının ancak diğer temel haklarla birlikte düşünüldüğünde anlamlı olduğu düşüncesinin kabulü, intihar etme, açlık grevi, ölüm orucu ve ötanazi arasında mevcut olduğu iddia edilen farkları belirsiz hale getirmekte, farklılık ve ayrımların tutarsız olduğunu ortaya koymaktadır.

Bu düşünceye karşı çıkan ve intihar, ölüm orucu, açlık grevi ve ötanazi arasında derin farklar olduğunu, ölme hakkından bahsedilemeyeceğini iddia edenlere göre, ${ }^{[17]}$ intihara teşebbüs edene ceza verilmemesinin nedeni yaşam hakkına istisna getirmek değil intihar sürecindeki bireyin ceza tehdidinden korkarak vazgeçmekte tereddüt geçirmesini önlemektir. Aynı şekilde bazı hukuk sistemlerinde ötanaziye ceza verilmemesi ya da cezadan indirim yapılmasının amacı da yaşam hakkına istisna getirmekten öte insani acıma hissine değer vermektir. Dolayısıyla intihara teşebbüs ve ötanazi durumlarında bile yaşam hakkına istisna getirildiği savunulamazken, açlık grevleri ve ölüm oruçlarında yaşam hakkına istisna getirildiği ve bu eylemlere müdahale edilemeyeceği düşüncesinin kabul edilemez olduğu belirtilmektedir. ${ }^{[18]}$ Oysa burada kanımızca savunulan husus, yaşam hakkına

[15] Feyzioğlu, s.157-158, 162.

[16] Sevinç, s.133-134.

[17] Akıncı, s.740-741; Ömeroğlu, s.95; Taşkın, s.556; Arzu Beşiri, "Ötanazi ve Yaşam Hakkı", TBB Dergisi, S.86, 2009, s.201; Serkan Cengiz, "Mahpusların Açlık Grevi Ve Zorla Besleme Paradoksu Işığında Hekim Sorumluluğu”, TBB Dergisi, 2010, S.88, s.423, 425.

[18] Ömeroğlu, s.95-96. Kanımızca, pasif ötanazi ile intihar arasındaki tek fark, intihar- 
istisna getirilip getirilmediğinden çok yaşam hakkı ile diğer temel haklar birbiriyle çatıştığında neden yaşam hakkına üstünlük tanıdığımız ve yaşam hakkından ne anladığımız noktasında farklılık göstermektedir.

Yaşam hakkının üçüncü kişilerin harici müdahalelerine karşı savunulması gerektiği tartışmasızdır. Nitekim İnsan Hakları Evrensel Beyannamesinin 3., AİHS’in 2. maddesi yaşam hakkını dış müdahalelere karşı korumaktadır. Buna göre, yaşam hakkı, kamu makamları tarafından öldürülmeme ve yaşama yönelmiş tehlike ve risklere karşı yine yaşamın kamu makamları tarafından korunması hakkını içerir. ${ }^{[19]}$ Ancak kişinin kendi vücut bütünlüğü üzerinde tasarrufta bulunup bulunamayacağını, yaşam hakkından vazgeçmenin mümkün olmadığı ve insan yaşamının kutsallığı ile açıklamak hukuki bir yaklaşımdan çok felsefi ya da teolojik bir ön kabul olarak gözükmektedir. Nitekim AİHM'in AİHS' in 2. maddesinde yer alan yaşam hakkının ölüm hakkını içermediğine ilişkin Pretty kararında bile 2 . maddenin hayatın kalitesi ve herhangi bir kimsenin kendi hayatı ile ilgili olarak ne yapmayı tercih ettiği hususuyla ilgili olmadığı açıkça belirtilmektedir. Mahkemeye göre, bu hususların insan yaşamı için devletin müdahale alanından çıkarılmayı gerektirecek derecede esaslı bir unsur olduğunun kabul edilmesi halinde Sözleşme’nin diğer maddelerinde ele alınması veya insan haklarına ilişkin diğer belgelerde düzenlenmesi mümkündür. ${ }^{[20]}$ Yine Mahkemeye göre, herhangi bir devletin, üçüncü bir kişinin veya kişinin bizzat kendisinin vücut bütünlüğüne zarar vermesini mümkün kılan düzenlemeler yapması veya yapmak istemesi halinde bu durum kişisel özgürlükler ile kamu yararının çatışıp çatışmadığı hususunun denetlenmesini gerektirebilecek ve bu husus ancak her olayın kendi şartlarında ve somut özelliklerine göre çözülebilecektir. ${ }^{[21]}$

Yine açlık grevinde temel bir haktan vazgeçildiği ve bunun meşru olmadığı düşüncesine karşı, vazgeçme ile feragat etme, terk etme ve devret-

da ilgili ruhen veya bedenen bir engeli bulunmadığı için ölüm kararını tek başına alıp uygulayabilmekte iken pasif ötanazide ilgili psikolojik veya bedensel engeller sebebiyle ölüm kararını alamamakta, alsa bile uygulayamamaktadır. İlgili ötanazi konusunda üçüncü bir kişinin desteğine ihtiyaç duymakta, bu desteği de hekimlerden talep etmektedir. Bu kararın uygulanmasına ilişkin masraflara da ya kendisi katlanmakta ya da devletten destek almaktadır.

[19] M. Sezgin Tanrıkulu, "İHAM Kararlarında ve Türk Hukukunda Yaşam Hakkı", TBB Dergisi, 2006, S.66, s.52.

[20] Pretty v. the United Kingdom (no. 2346/02), \$39, 29 April 2002.

[21] Pretty v. the United Kingdom, $\$ 41$. 
me kavramları arasında farklar bulunduğunu belirtmek gerekir. ${ }^{[22]}$ Örneğin temel bir hak olan mülkiyet hakkı, kullanma, semerelerinden yararlanma ve yok etme unsurlarını içermektedir. Bir kimsenin maliki olduğu bir eşyayı üçüncü bir kişiye devretmesinde veya bir daha kullanmamak üzere üçüncü bir kişiye bırakmasında ortaya çıkan durum mülkiyet hakkından vazgeçmek değildir. Nitekim Feinberg'e göre, bu durumda sadece o malın mülkiyetinden feragat edilmiş, bir hak olarak mülkiyet hakkından tümüyle vazgeçilmemiştir. Bu tür bir işlem, mülkiyet hakkının sağladığı unsurları kullanmanın yollarından biri olarak düşünülebilir. Benzer şekilde, yaşamak yerine yaşamamayı seçmek de yaşama hakkından vazgeçmek olarak değil yaşamın kendisinden feragat etmek olarak değerlendirilebilir. ${ }^{[23]}$ Benzer bir yorumda bulunan Wellman'a göre de tedaviyi reddetme sonucunu doğuran pasif ötanazide yapılan şey "vazgeçme/devretme" değil "feragat etme/terk etme" ya da "yetkilendirme" dir. Böylece Wellman’a göre, pasif ötanazide yaşamayı tercih etmemek, yaşama hakkından vazgeçildiği ya da bu hakkın devredildiği anlamına gelmemektedir. Dolayısıyla "ötanaziyi seçmek ve bu yolla ölmek" yaşama hakkından vazgeçmek değildir. Aksine yaşam hakkını tam bir özgürlükle kullanmaktır. Çünkü pasif ötanazide kişi tedaviyi reddederek sadece tedavi görme hakkından feragat etmekte, bu hakkı terk etmekte ya da kullanmamaktadır. ${ }^{[2]}$

Dolayısıyla, serbest iradenin ürünü olduğunda tereddüt bulunmayan açlık grevlerine yaşamın kutsallığı veya temel haklardan vazgeçilemeyeceği düşüncesiyle yapılan müdahaleler, yaşam hakkını, "kişinin hayatta kalma" hakkına indirgemekte, ${ }^{[25]}$ hayatın sosyal ve ideale dayalı yönünü ihmal ederek müdahaleyi meşrulaştırmakta yetersiz kalmaktadır. Zaten hükümlü veya tutuklunun serbest iradesinin ürünü olmayan açlık grevlerinde, TCK'nın 298/2. maddesi gereğince hükümlü ve tutukluların beslenmesini engelleyenler, açlık grevine veya ölüm orucuna teşvik ya da ikna edenler veyahut bu yolda talimat verenler beslenmenin engellenmesi suçundan sorumlu olacaklardır. Yine, "hükümlü ve tutukluların beslenmelerini engellemek, açlık grevine ve ölüm orucuna teşvik veya ikna etmek, bu yolda ta-

[22] Joel Feinberg, "Voluntary Euthanasia and the Inalienable Right to Life", Philosophy and Public, 1978, Y.7 S.2, s.115, 117, aktaran: Ertuğrul Cenk Gürcan, "Ötanazi: Yaşama Hakkı Açısından Bir Değerlendirme”, AÜHFD, 2011, Y.60 S.2, s.272-273.

[23] Feinberg, s. 117, aktaran: Gürcan, s.273.

[24] Carl Wellman, "The Inalienable Right to Life and the Durable Power of Attorney", Law and Philosophy, 1995, Y.14, S.2, s. 256, 260, aktaran: Gürcan, s.271- 272.

[25] Sevinç, s.133. 
limat vermek", Ceza ve Güvenlik Tedbirlerinin İnfazı Hakkında Kanun'un 44/2-m maddesi gereğince, hücreye koyma yaptırımı ile cezalandırılan bir disiplin suçu olarak da düzenlenmiştir. Bu nedenle, serbest iradenin ürünü olduğunda tereddüt bulunmayan açlık grevlerine yaşamın kutsallığı gerekçesiyle yapılan müdahale, insan iradesini, özellikle bedeni dışında kısıtlı ifade aracına ve olanağına sahip olan hükümlünün kendi bedeni üzerinde tasarruf iradesini yok saymakta, greve neden olan hususları ve eylemcinin talebini daha baştan görmezden gelmekte, devletin hükümlünün bedeni üzerinde mutlak tasarruf yetkisinin olduğu düşüncesinin zorla kabul ettirilmesine ve insan bedeninin kamu otoritesi karşısında nesneleştirilmesine sebep olmaktadır. Bu bağlamda, aşağıda ayrıntılı olarak açıklanacağı üzere, direnme hakkı, hak arama özgürlüğü ve düşünceyi ifade özgürlüğü kapsamında, açlık grevi, bireyin özne olarak irade serbestisinin tanınması 1srarından ibarettir. ${ }^{[2]}$ Yine, bireyin yaşam hakkı üzerinde tasarruf edemeyeceğini, devletin hükümlü ve tutukluların sağlığını korumakla yükümlü olduğunu $^{[27]}$ ve yaşam hakkının kapsamına ölüm hakkının girmediğini savunmak, devletin ve toplumun bu hakkı kişi adına elinde tuttuğunu söylemek anlamına gelir ki hukuk devleti anlayışında böyle bir belirlemede bulunmak kabul edilemez. ${ }^{[28]}$

Bugün artık "yaşamın kutsallığı tezinden", "yaşamın niteliği” tezine yani, yaşamın kalitesi ve iyiliği noktasından bireyin özgür tercihlerinin belirleyiciliği noktasına gelinmiştir. Yine günümüzde insan hakları anlayışı, onur ve saygınlık sahibi, ahlaki seçim yapabilen, serbestçe karar verebilen, davranışlarını kendisi yönlendirebilen özgür insan modeli üzerine kurulmuştur. Bu özelliklere sahip olduğu varsayılan insana dolayısıyla kendisiyle ilgili kararları alma yetkisi tanınmalıdır. ${ }^{[2]]}$ Yaşam hakkını koruyacak tedbirleri almak devletin görevidir. Ancak devletin yaşamı koruma ve kişiyi yaşatma ödevi kişinin iradesi hiçe sayılarak zorla yerine getirilemez. ${ }^{[30]}$ Kişi açıkça beslenme ve tedaviyi reddediyorsa bilinci açık iken açlık grevini ölüm riskini göz önüne alarak sonuna kadar devam ettireceğini belirtiyor ise devletin yaşamı koruma görevi olduğu, yaşam hakkının ölme hakkını içermediği ve kişinin de yaşama ödevi olduğu gerekçesiyle ilgilinin tedavi-

\footnotetext{
[26] Eren, s.137.

[27] Önok, s.180.

[28] Serdaroğlu, s.487.

[29] Özen/Şahin, s.30.

[30] Özen/Şahin, s.31.
} 
ye zorlanması hukuka aykırılık teşkil eder.

\section{B. Açlık Grevi, İrade Serbestisi ve Temel Hakların Kötüye Kullanılamaması}

Açlık grevinde amaç gerçekten de ölmek değil çoğu zaman daha iyi bir yaşam için gerekli olduğuna inanılan talepleri kabul ettirebilmektir. Bunun için elde kalan son koz olan yaşamayı tercih etmeme söz konusudur. Grevciler, hiç kimsenin, bir insanın göz göre göre ölümü karşısında kayıtsız kalamayacağı inancıyla hareket ederler. Açlık grevi yapan kişi, amacına ulaşmak için en temel gereksinimini, yani beslenmeyi terk etmekte ve bu yolla diğer tüm temel hakların da kaynağı olan "yaşama hakkı" nı kullanmayı tercih etmemektedir. ${ }^{[31]}$ İlkeler doğrultusunda şekillenen ideal yaşama ulaşmak adına, nefes alıp vermekten ibaret tıbbi manada yaşamı daha fazla tercih etmeyen bir eylemci için açlık grevi bir kararlılık göstergesi ve kişinin kendi iradesiyle üzerinde tasarrufta bulunabileceği tüm haklara yönelik irade serbestisi ilkesinin sınırlarının sonuna kadar zorlanmasının bir ifadesidir. Özellikle, hükümlüler açısından hapis cezaları bedenin belli bir yere kapatılması suretiyle uygulandığından, hükümlülerin protesto ve direniş biçimleri de temelde beden üzerinden gelişmekte, insan bedeni bir "araç veya aracı" hâline getirilerek direnebilmekte, insan bedeni bir tebliğe, protestonun ya da taleplerin göstergesine çevrilebilmekte, talepler bu şekilde dile getirilebilmektedir. ${ }^{[32]}$

Ancak açlık grevinin yaşam hakkından vazgeçmeye neden olması ve temel bir haktan vazgeçilemeyeceği düşüncesinin yanında, açlık grevinde irade serbestinin ve temel hakların kötüye kullanıldığı, bu nedenle de açlık grevlerinin savunulamayacağı iddia edilmektedir. ${ }^{[33]}$ Nitekim İspanya'da GRAPO'nun (Grupos de Resistencia Antifascista Primero de Octubre - 1 Ekim Anti-Faşist Direniş Grupları) düzenlediği açlık grevleri sırasında konu hakkında görüş bildiren İspanyol anayasa hukukçusu M. Aparicio, siyasi amaçla yapılan grevin, temel bir hakkın kötüye kullanılması olduğunu savunmuştur. Aparicio'ya göre, kısıtlı kişilerin kendi yaşamları konusunda karar verme hakları yoktur ve devletin görevi onların yaşam ve sağlığını korumaktır. Belirli hakların, o hakların içeriğiyle ilgisi olmayan amaçlar için kullanılması durumunda temel hakların kötüye kullanılması söz ko-

\footnotetext{
[31] Önok, s.142; Sevinç, s.113

[32] Eren, s.127.

[33] Sevinç, s.131, 132.
} 
nusudur ve bu durumda zor kullanılarak yapay beslenme yöntemine de başvurulabilir. ${ }^{[34]}$

Sevinç tarafından da aktarıldığı üzere, eğer açlık grevinin, Anayasa’nın 26. maddesine uygun olarak düşünceyi açılama ve yayma hürriyeti kapsamında bir temel hak olduğu ve asıl amacın "ölmek" olmadığı kabul edilirse eylemin yöneldiği amacın "yaşam hakkını" ortadan kaldırmak olmadığı, dolayısıyla bir temel hakkın kötüye kullanılmasının söz konusu olamayacağı da kabul edilebilir. ${ }^{[35]}$ Nitekim ölümü amaçlayarak bilerek ve isteyerek yaşam hakkından vazgeçmek ile istenen sonuç ölüm olmamasına rağmen ölümün gerçekleşeceğini öngörmek arasında fark vardır. Bu nedenledir ki sonuç alınamayan tedavinin kesilmesi ve bu şekilde öngörülen ancak amaçlanmayan ölüm sürecinin hızlandırılması şeklinde gerçekleşen pasif ötanazi tıp ve hukuk dünyasında yaygın taraftar bulurken, ani ölüme neden olan, öldürmeye yönelik amaçlanan eylemin fail/doktor tarafından bilerek ve istenerek gerçekleştirildiği aktif ötanazi yaygın bir kabul görmemekte, tereddütler bulunmaktadır. ${ }^{[36]}$ Açlık grevinde, eylemcinin amacı gerçekten de ölmek değil nefes alıp vermekten öte daha iyi bir yaşam sürmektir. Bu amaçla yapılan grevde, durumu kötüleşen eylemcinin zorla yapay yollarla beslenmesi - zorla besleme tıbbi müdahalenin tek şekli olmamakla beraber ${ }^{[37]}$ - eylemciyi hayata döndürecek tedavinin ya da tıbbi müdahalenin esasını oluşturmaktadır. Nasıl ki pasif ötanazide hasta daha fazla yaşamak için tıbbın sunduğu mevcut olanakları reddedebiliyorsa eylemci de zorla yapay besleme şeklindeki tedaviyi reddedebilmelidir. Nitekim beslenme ihtiyacı olan bir hastaya bilinçli olarak ihtiyacı olan besin desteğinin verilmemesinin pasif ötanazi olduğu, Cruzan vakası olarak bilinen vakada kabul edilmiştir. Bu vakada, 25 yaşında geçirdiği kaza sonucunda bitkisel hayata giren ve sekiz yil bitkisel hayatta yapay olarak beslenen Nancy Cruzan'ın beslenme tüplerinin çekilmesi suretiyle yaşamına son verilmesi yönünde ailesinden gelen talebi kabul eden Missouri Mahkemesi'nin kararının, Amerikan Yüksek Mahkemesi tarafından onandığı belirtilmekte-

[34] Cemal, Bali Akal, "İspanyàda Açlık Grevlerinin Doğurduğu Sorunlar”, Argumentum, Şubat 1992, Y.2, S.19, s. 293, aktaran: Sevinç, s.131

[35] Sevinç, s.132.

[36] Gürcan, s.265; Hamide Zafer, Ceza Hukuku Genel Hükümler, 7.Bası, Beta, İstanbul, 2019, s.402-405; Veli Özer Özbek/Koray Doğan/Pınar Bacaksız, Türk Ceza Hukuku Genel Hükümler, 10.Baskı, Seçkin, 2019, s.330-333.

[37] Önok, s.143. 
dir. ${ }^{[38]}$ Yine yukarıda aktarılan Pretty ve ardından gelen Lambert ve diğgerleri kararında, AİHM, ölüm sonucunun istenmediği ama öngörüldügü hallerde, bir kimsenin bilinci yerinde iken yaşam süresini uzatacak tıbbi tedaviyi reddetmesi durumunda, ilgilinin bilinçli rızası veya aydınlatılmış onamı olmaksızın uygulanacak tedavinin Sözleşme'nin 8. maddesinin birinci fikrası anlamında hayat tarzına müdahale ve vücut bütünlüğünün dokunulmazlığının ihlali sayılabileceğini belirtmektedir. Dolayısıyla bir kimsenin hayat süresini uzatacak bir tedaviye rıza göstermemek suretiyle ölümü tercih etmesi mümkündür. ${ }^{[39]}$

Görüldüğü üzere, açlık grevinde bir hakkın kötüye kullanılması veya vazgeçilmesi söz konusu olmayıp açlık grevinde ve devamında ölüm orucunda, tıpkı pasif ötanazi durumunda olduğu gibi tedaviyi reddetme, tedavi görme hakkını kullanmama söz konusudur. Tedaviyi red hakkı kapsamında değerlendirilmesi gerektiği ve cezalandırılmaması gerektiği belirtilen pasif ötanazide ${ }^{[40]}$ nasıl ki ilgili zorla tedaviye tabi tutulmuyorsa açlık grevi yapan eylemci bilinci açık iken zorla beslenmeyi reddetmiş ise bu iradeye de saygı duyulmalı, bu iradeye saygı duyan hekimler için herhangi bir cezai sorumluluk doğmamalıdır. ${ }^{[41]}$ Ancak, bir kişi açlık grevini, cezaevinden cezasını tamamlamadan çıkmak için yaparsa bu durumda hakkın kötüye kullanılmasından söz edilebilir. Bu nedenle, açlık grevinin temel bir hakkın kötüye kullanılmasına sebebiyet verip vermediği her somut olayın özeliklerine göre belirlenmelidir. ${ }^{[42]}$ Bununla beraber, açlık grevine temel bir hakkın kötüye kullanıldığı gerekçesiyle yapılan müdahale, Anayasa’nın 13. maddesi gereğince eylemcinin düşünceyi açıklama ve yayma hürriyetinin özüne dokunamayacağı gibi demokratik toplum düzeninin gereklerine ve ölçülülük ilkesine de aykırı olamaz. Aksi durumda açlık grevine yapılan müdahale, hakkın kullanılmasının durdurulması veya askıya alınması anlamına gelebileceğinden, böyle bir durum Anayasa’nın 15. maddesi gereğince ancak savaş, sıkıyönetim ve seferberlik halinde söz konusu olabilir.

[38] Besiri, s.192-193.

[39] Pretty v. the United Kingdom, $\$ 63$; Lambert and Others v. France [GC], (no. 46043/14), \$180, 5 June 2015.

[40] Özen/Şahin, s.31.

[41] Karşı görüş için bkz. Önok s. 172-174.

[42] Sevinç, s.132. Temel bir hakkın kötüye kullanımı ve açlık grevi kapsamında, açlık grevi sırasında toplanma hakkının kötüye kullanıp kullanılmadığı ve müdahalenin orantılı olup olmadığı hakkında bkz. Cisse v. France, (no.51346/99), 9 April 2002. 
Buraya kadar yaptığımız açıklamalar ışığında, açlık grevi, arzu edilmeyen, kişisel olarak hiçbir şekilde desteklemeyeceğimiz, ancak başından sonuna kadar her zaman meşru bir eylem ve düşünceyi ifade biçimidir. Nitekim AİHM, ifade özgürlüğü kapsamında AİHS'in 10. maddesinin, ifade edilen fikir ve bilgilerin yalnızca içeriğini değil aynı zamanda aktarım şeklini de koruduğunu ifade etmiştir. Bu bağlamda, Mahkeme, insanların düşüncelerini, fikirlerini ve eleştirilerini genel yöntemlere kıyasla daha az aşikâr olan yöntem ve araçlarla aktarmaları ve ifade etmeleri halinde de Sözleşme'nin 10. maddesinin geçerli olduğunu belirtmiştir. ${ }^{[43]}$ Bu nedenle, bir hakkın yine hukuk düzenince izin verilen yöntemler ile talep edilmesi gerektiği, bu nedenle hak arama hürriyetinin sadece idareye ve yasama organına dilekçe verme ve yargı mercilerine başvurmak yöntemlerini kapsadığı, dolayısıyla amacı her ne olursa olsun açlık grevlerinde kullanılan yöntemin meşru olmadığı ve hak arama hürriyeti kapsamında değerlendirilmeyeceği düşüncesine ${ }^{[44]}$ katılmıyoruz.

Ancak Anayasa Mahkemesi ceza ve infaz kurumlarında hükümlü ve tutuklular tarafından yapılabilecek açlık grevlerini ifade özgürlüğü kapsamında değerlendirmemekte, bir disiplin sorunu olarak görmekte, cezanın yerine getirilmesine katlanma yükümlülügünün ihlâli saymakta, disiplin cezasıyla cezalandırılmasını hukuka uygun bulmaktadır. Nitekim aşağıda da ayrıntılı olarak tartışılacağı üzere, cezanın yerine getirilmesine katlanma yükümlülüğünün açlık grevi yapılarak ihlali halinde uygulanması gereken "bazı etkinliklere katılmaktan alıkoyma" disiplin cezasının (CVGTIHH m.40/2-g), ifade özgürlüğüne yönelik ölçüsüz bir sınırlama olduğu gerekçesiyle iptali istemiyle yerel mahkemelerce yapılan itiraz başvuruları, Anayasa Mahkemesi tarafından reddedilmiştir. Anayasa Mahkemesi söz konusu kararında, "ceza infaz kuramlarmın, yapıları gereği hürriyetin stnırlandırlldiğz ve Devletin kontrolü altındaki özel alanlar olması ve dolayzsiyla Devletin hem bu kurumda bulunanların güvenliklerini ve sağllklarnn koruma hem de disiplini tesis etme yükümlülü̈̆̈̈nün bulunması karşısında, bükümlülerin ve tutuklularn da ceza infaz kurumlarnnda diledikleri şekilde eylem yapma özgürlüğünün bulunmadiğg, kamu düzeninin sağlanması amacıyla bükümlülerin ifade özgürlügüune bir sinırlandırma getirildiği, sinırla-

[43] Kılıçdaroğlu v. Turkey (no.16558/18), § 62, 27 October 2020; Murat Vural / Türkiye (Başvuru no.9540/07), $\$ 44,21$ Ekim 2014; Mustafa Erdoğan ve diğerleri / Türkiye (Başvuru no.346/04 ve 39779/04), \$ 45, 27 Mayıs 2014; Oberschlick v. Austria (no. 11662/85), $\$ 57,23$ May 1991.

[44] Taşkın, s.555-556. 
manın kanunla ve Anayasänın 26. maddesinde belirtilen özel sinırlandirma nedenine bağlı kalınarak yapıldı̆ğ " gerekçesiyle itiraz talebinin reddine karar vermiştir. ${ }^{[45]}$ 9'a karşı 6 oyla oyçokluğuyla alınan bu kararda, itirazın reddi yönünde oy kullanan üyelerce, açlık grevinin hukuki niteliğine yönelik herhangi bir detaylı tartışma yapılmadığı gibi AİHM'in açlık grevine müdahaleye ilişkin içtihatlarına da herhangi bir atıf yapılmamıştır. Buna karşılık karşı oy yazılarında, bu makalede de belirtildiği üzere, açlık grevinin AİHS'in 9. ve 10. maddesinde yer alan düşünce ve ifade özgürlüğü bağlamında korunduğu ve bu özgürlüğün kullanımında ifade tarzları arasında bir ayrım bulunmadığı ifade edilmiştir. Ardından, CVGTİHK'nın 40/2-g maddesinde, açlık grevinin cezaevi güvenliğini bozucu halleri ile masum bir demokratik tepki olarak bireysel tercih sonucu ifa edilen halleri arasında hiçbir ayrım yapılmadığı, bu durumun eylemi yorumlayacak kişiler yönünden açıkça keyfilik ve kişiden kişiye değişecek belirsizlik içerdiği, müdahaleye meşruluk verecek güvenceden yoksun olduğu, bu nedenle Anayasa’nın 26. maddesi bağlamında Anayasa’nın 2. maddesinde yer alan hukuk devleti ilkesine aykırı olduğu belirtilmiştir. ${ }^{[46]}$

$\mathrm{Bu}$ nedenle, hayati risk aşamasına gelmiş açlık grevine müdahale edilip edilmeyeceği sorunu, meşruiyetten çok mazeret nedeninin veya hukuka uygunluk nedenlerinin bulunup bulunmadığ sorunudur. Bu durumda, açlık grevlerine veya ölüm oruçlarına hangi hallerde müdahale edilebileceği, hangi hallerde sınırın aşılmış sayılması gerektiği, hukuka uygunluk nedenleri açısından ele alınıp incelenmelidir.

\section{II- AÇLIK GREVINE MÜDAHALE SORUNU VE HUKUKA UYGUNLUK NEDENLERI}

"Mazeret nedenleri" ya da "suçu ortadan kaldıran objektif nedenler" olarak da adlandırılan hukuka uygunluk nedenleri 5237 sayılı TCK'da "Ceza Sorumluluğunu Kaldıran veya Azaltan Nedenler" başlığ 1 altında (m.24-26) düzenlenmiş olup bu nedenler fiilin hukuka aykırılığını kaldırıp hukuka uygun bir şekilde ortaya çıkmasını sağlarlar. ${ }^{[4]} \mathrm{Bu}$ itibarla, ceza

[45] Çankırı İnfaz Hâkimliği ve Kara Kuvvetleri Komutanlığı Askeri Mahkemesi tarafindan yapılan itiraz başvurusu üzerine Anayasa Mahkemesince verilen 10.10.2013 tarih ve E.2013/6, K.2013/111 sayılı karar. R.G. Tarih-Sayı: 09.05.2014-28995.

[46] Karşı oy yazıları AYM, 10.10.2013 tarih ve E.2013/6, K.2013/111 sayılı karar. R.G. Tarih-Sayı: 09.05.2014-28995.

[47] Nevzat Toroslu, Ceza Hukuku Genel Kısım, Savaş, Ankara, 2012, s.149. 
hukukçularının çoğunlukla açlık grevinin hukuki niteliğine bütüncül ve sistematik bir yorumla yaklaşmak yerine, bir dereceye kadar zorlama yorumlarla, açlık grevine müdahalenin nasıl mümkün olabileceği konusuna yoğunlaştığı, konuya ilişkin eserlerin bazılarının mülga 765 sayılı TCK dönemine ait olduğu ve yazarların görüşlerini 5237 sayılı TCK kapsamında yeniden değerlendirmeye tabi tutmadıkları görülmektedir. ${ }^{[48]}$

Örneğin Feyzioğlu’nun konuya ilişkin yaklaşımı esas itibarıyla "açlık grevinin ölüm sonucunu doğurmadan önce kişiye kalıcı bir takım zararlar verme tehlikesine neden olduğu andan itibaren meşruiyetini kaybettiği" "499] düşüncesine dayanmaktadır. Bu görüşe katılmak mümkün değildir. Çünkü açlık grevi hayati tehlikenin oluştuğu andan itibaren gayri meşru kabul edilirse idarenin bu andan itibaren ölüm sonucunun önlenmesi için eylemcinin isteğini kabul etmesi, gayri meşru bir eyleme boyun eğilerek karar alındığı sonucunu doğurur. Dolayısıyla bu açıdan bakıldığında, idarenin kabule ilişkin kararı, rüşvet karşılığında veya tehdit altında alınan hukuka aykırı karardan farksız hale gelir. Bu görüşün kabulü yine, idarenin eylemcinin talebiyle uyumlu aynı idari kararının hayati tehlikeden önce meşru, hayati tehlikeden sonra gayri meşru olduğu çıkarsamasında bulunmamıza neden olur ki aynı kararın hem gayri meşru hem meşru sayılmasının mantıki tutarsızlı̆̆ı ortadadır.

Yine Feyzioğlu’na göre, açlık grevine müdahale edenin, üçüncü kişi lehine meşru müdafaa hükümlerinden yararlanması mümkündür. ${ }^{[50]}$ Ancak açlık grevine müdahale edenin, üçüncü kişi lehine meşru müdafaa hükümlerinden yararlanabileceğini söyleyebilmek için kişinin kendi bedeni üzerinde aç kalmak suretiyle yaptığı müdahaleyi "haksız saldırı" olarak nitelemek gerekir. Bu durumda açlık grevi yapan kişi, hem vücudu üzerinde haksız saldırıda bulunulan mağdur, hem de haksız saldırıyı yapan fail konumundadır. Oysa Anayasa'nın 26., Türk Medeni Kanunu'nun 23. ve 24. maddeleri göz önüne alındığında bir kimseye yemek yeme mükellefiyeti yükleyen norm olmadığ 1 gibi bir kimsenin kendisine eziyet etmesini engelleyen norm da yoktur. ${ }^{[51]}$ Askeri Ceza Kanunu'nun 79. maddesi gereğince, bir kimsenin kendisini askerliğe elverişsiz hale getirmesi hali suç olarak öngörülmesine rağmen bu durumda fail ve mağdur sıfatları birleş-

[48] Akıncı, Feyzioğlu, Soyaslan, (Açlık Grevi).

[49] Feyzioğlu, s.163.

[50] Feyzioğlu, s. 166,167.

[51] Akıncı, s.750-751. 
memektedir. Bu suç türünde, kişi kendisine eziyet ettiği için değil askerlik hizmetini yapmasına ilişkin bir menfaati ihlal ettiği için cezalandırılmakta ve suçun mağduru menfaati ihlal edilen devlet olmaktadır. Yine TCK'nın kabul ettiği sistematik içinde TCK'nın 91. maddesinde öngörülen organ veya doku ticareti suçu hariç, aynı kişinin bir suçun hem faili hem de mağduru olamayacağı ilkesi kabul edilmiştir. ${ }^{[52]}$ Bir kimsenin aynı anda bir eylemin hem faili hem de mağduru olması düşünülemeyeceğine göre, bu düşünce de zorlama bir düşüncedir. Yine aşağıda ayrıntılarıyla açıklanacak, Avrupa Konseyi Biyotıp Sözleşmesi'nin ${ }^{[53]} 5$. ve 9. maddesinin öngördüğü tıbbi müdahale ve tedaviyi reddetme hakkı dikkate alındığında, yapay beslenmeyi reddetmenin haksız saldırı olduğunu kabule olanak kalmamaktadır. Açlık grevine yapay beslenme yoluyla zor kullanarak müdahale etmek de bir tıbbi müdahale olup hukuk sistemleri hukuka uygunluk nedenleri konusunda kendi içinde çelişkiye düşemez. Yani bir hareket tarzını hak olarak kabul ettikten sonra, aynı hareket tarzını haksız saldırı sayamaz. ${ }^{[54]} \mathrm{Bu}$ durumda meşru savunma hükümlerinin de uygulanması mümkün olamayacaktır. ${ }^{[5]}$

Açlık grevine müdahale halinde hukuka uygunluk nedenlerinin uygulanıp uygulanmayacağı sorusuna cevap arayan Soyaslan'a göre, kişinin kendi vücut bütünlüğü üzerindeki tasarruf hakkı, vücut bütünlüğünü bozma değil geliştirme yönünde verilmiş bir haktır. Dolayısıyla kişinin sağlığını geliştirmeyi ve iyileştirmeyi amaçlamaktadır. Nasıl ki bir kimsenin yemek yemesini engelleyen diğer bir kimse ilk etapta etkili eylemden, ardından ölümden sorumlu tutuluyor ise kişinin kendini aç bırakma eylemi de ceza kanunu açısından suç değil ise de ceza kanunu tarafından tasvip edilmeyen, hukuka aykıı bir fiildir. Çünkü eylemci sağlığını geliştirme ve

[52] TCK’nın 91. maddesinde öngörülen organ veya doku ticareti suçları düzenlenirken, aynı kişinin bir suçun hem faili hem de mağduru olamayacağı ilkesi gözden kaçmıştır, Toroslu, s.105; Tuğrul Katoğlu, "Ceza Hukukunda Suçun Mağduru Kavramının Sinırları”, $A \ddot{U H} H F D, 2012$, Y. 61, S.2, s.663.

[53] Kısa adıyla "Avrupa Konseyi Biyotıp Sözleşmesi” olarak bilinen Avrupa Konseyi "Biyoloji ve Tibbın Uygulanması Bakımından İnsan Hakları ve İnsan Haysiyetinin Korunması Sözleşmesi: İnsan Hakları ve Biyotıp Sözleşmesi” , Avrupa Konseyi tarafından 4 Nisan 1997 tarihinde imzaya açılmış, 9 Aralık 2003 gün ve 25311 sayılı Resmi Gazete'de yayınlanarak yürürlüğe giren 5013 sayılı Kanun ile iç hukukumuzun bir parçası haline gelmiştir.

[54] Toroslu, s.149,151.

[55] Ömeroğlu, s.102. 
iyileştirme amacı içermeyen bir davranışla vücut bütünlügü üzerinde ve kendisine ait olmayan bir hak üzerinde tasarrufta bulunmaktadır ve bu da hukuka uygun değildir. ${ }^{[56]}$ Ancak vücut bütünlüğü üzerindeki tasarruf hakkının, sadece sağlığı korumak ve bedeni geliştirmek üzere verilmiş bir hak olduğunun kabulü, tamamıyla estetik kaygılar ile vücut üzerinde yapılan küpe takma, piercing (halka takma), yağ aldırma, dudak doldurma, kulak küçültme gibi müdahalelerin hukuka uygunluğunu tartışmalı hale getirir.

Aynı şekilde Soyaslan tarafından ileri sürülen rıza olmadan açlık grevine müdahale eden kimsenin zaruret halinden yararlanabileceği düşüncesi de eksiktir. Bu bağlamda Soyaslan’a göre, açlık grevine müdahale ederek başkasını hayati bir tehlikeden kurtaran kimse, aslında topluma ait olan hayatı kurtarmaktadır. ${ }^{[5]}$ Dolayısıyla, hastanın direncini zorla kırarak hastayı kurtaran kişi, üçüncü kişi lehine hem meşru müdafaa hem de ıztırar halindedir. ${ }^{[58]}$ Fakat bilindiği üzere zaruret halinden yararlanabilmek için kişinin tehlikeye yani açlık grevi nedeniyle oluşan ölüm tehlikesine bilerek sebebiyet vermemesi gerekir. ${ }^{[59]}$ Oysa tehlikeyi eylemcinin kendisi yapay beslenmeyi reddederek yaratmaktadır.

Kanımızca açlık grevine müdahalede bulunan kimsenin meşru müdafaadan ya da zaruret halinden yararlanabileceğine ilişkin düşünceler, hukuka uygunluk nedeninin bulunduğu hallerde fiilin artık hukuka aykırı sayılamayacağı ve tüm hukuk düzeni ile çatışma halinde bulunamayacağ 1 gerçeğini göz ardı etmektedir. ${ }^{[60]}$ Müdahaleye belli bir aşamadan sonraya izin verilmesinin meşru, belli bir aşamadan önce izin verilmesinin meşru olmadığı tartışması buradan kaynaklanmaktadır. Oysa "davranış ile hukuk düzeni arasındaki bir çelişki anlamında hukuka aykırılık derecelendirilemez." ${ }^{[61]}$ Hukuka aykırılık ya vardır ya da yoktur. Dolayı-

[56] Soyaslan, Açlık Grevi, s.277-278.

[57] Soyaslan, Açlık Grevi, s.279.

[58] Doğan Soyaslan, Ceza Hukuku Genel Hükümler, 8.Baskı, Yetkin, Ankara, 2018, s.366.

[59] Soyaslan, Ceza Hukuku, s.399; Toroslu, s.168; Zafer, s.389; Bahri Öztürk/Mustafa Ruhan Erdem, Uygulamalı Ceza Hukuku ve Güvenlik Tedbirleri Hukuku, 17.Bask1, Seçkin, 2017, s.251, 253.

[60] Özbek/Doğan/Bacaksız, s.276; Özgenç, s.313, 317; Öztürk/Erdem, s.228-229; Soyaslan, Ceza Hukuku, s.359; Toroslu, s.149,150; Zafer, s.352.

[61] Öztürk/Erdem, s.229. Aynı düşünceler için ayrıca bkz. Özgenç, s.317; Toroslu, 
sıyla aç kalmak suretiyle besin almaya ve yapay beslenmeye direnme, ya baştan itibaren hukuka uygun ya da hukuka aykırıdır ve bu husus tüm hukuk düzenine bakarak belirlenir.

Kanaatimizce açlık grevine müdahalede cezai müeyyideyi ortadan kaldırabilecek tek olasılık hekimler için geçerli olan ve TCK'nın 24. maddesinde yer alan "kanun hükmünü yerine getirme" halidir. ${ }^{\left[{ }^{[2]}\right]}$ Ancak burada, kanımızca, hukuka uygunluk nedeni yerine hekimlik mesleğini icra eden kimselere tanınmış kusurluluğu ortadan kaldıran kişisel bir cezasızlık sebebi söz konusudur demek daha doğru olur. Aksi bir yorum, asıl failin eyleminin hukuka aykırı olmadığı veya kastının bulunmadığı hallerde, diğer şeriklerin de kastının olmadığı veya hukuka aykırı davranmadığını öngören iştirakte bağlılık kuralı gereği (TCK, m.40/1), hekimle birlikte açlık grevine müdahale eden kimselerin de ceza sorumluluğunun bulunmadığı sonucuna varmamıza neden olur ki kanaatimizce hekimlik mesleğinin icrasına ilişkin ulusal ve uluslararası düzenlemeler buna izin vermemektedir. ${ }^{[63]}$ Burada kanunun, belirli statüde olan kişilere, görevleriyle ilgili ve görevlerinin verdiği yetki sınırı içinde yaptıkları hareketin hukuka aykırı olmayacağını belirtmesi söz konusudur. ${ }^{[64]} \mathrm{Bu}$ itibarla, bu tür hallerde sınırlı kişilere tanınmış "görevin ifası" veya "görevin yerine getirilmesi" şeklinde bir hukuka uygunluk nedeninden söz etmek daha uygun olacaktır. Çünkü bu tür durumlarda, ilgili kişi açısından bir görev vardır ve bu görevin yerine getirilmesi sırasında sınırın aşılıp aşılmadı̆̆ı, hukuka uygun hareket edilip edilmediği görevin mahiyeti ile bağlantılı olarak belirlenebi-

s.149-150.

[62] Aynı görüş için bkz. Önok, s.152. Doktrinde Soyaslan (Ceza Hukuku s.366), hekimin tıbbi müdahalesini ceza kanunda yer almayan hukuka uygunluk sebebi olarak kabul ederken, Zafer (s.397), Öztürk/Erdem (s.260), Özbek/Doğan/Bacaksız (s.312) tıbbi müdahaleyi TCK'nın 26.maddesi kapsamında hakkın icrası olarak değerlendirmektedir. Özgenç ise hekimin tıbbi müdahalesini rıza kavramı üzerinden açıklamakta, ayrıca hekimin kanun hükmünü icra ettiğini ve görevi yerine getirdiğini belirtmektedir, s.330-331, 387-390.

[63] Tibbi Deontoloji Nizamnamesi, 19.2.1960 tarih ve 10436 sayılı Resmi Gazete, m.6; Avrupa Konseyi İşkenceyi Önleme Komitesi Cezaevlerinde Sağlık Hizmetleri Raporu (1993), m.45, 46, 47; Dünya Hekimler Birliği Malta Bildirgesi, 1991, Giriş, m.3, m.4 Açlık Grevlerinin Yönetiminde Temel İlkeler, m.4; 1219 sayılı Tababet ve Şuabatı Sanatlarının Tarzı İcrasına Dair Kanun m.70; Avrupa Konseyi İnsan Hakları ve Biyotıp Sözleşmesi, m.5, m.9; Hasta Hakları Yönetmeliği 01.08.1998 tarih ve 23420 sayılı Resmi Gazete, m.22, 24, 25.

[64] Öztürk/Erdem, s.235. 
lir. ${ }^{[65]}$ Bununla beraber, hukuk normundan ya da kanundan kaynaklanan görevi yerine getiren kimsenin fiilinin hukuka uygun sayılabilmesi için fiilin görevin kaynağını oluşturan hukuk normunun belirlediği bütün şartlara uygun biçimde gerçekleştirilmiş olması gerekir. ${ }^{[66]}$ Kanun tarafından kendisine yetki ve görev verilmeyen kamu görevlileri kanun hükmünü icra ettiğini iddia edemez, başka bir deyişle hekim burada yetkisini doğrudan kanundan alır. ${ }^{[6]}$ Hekimin kendisine tanınan sınırlar içerisinde hareket etmesi halinde, hekimin talimatları doğrultusunda hareket eden diğer sağlık personeli için ise TCK'nın 24. maddesinin ikinci ve devamı fikralarında düzenlenen yetkili merciin emrini yerine getirme söz konusu olacaktır.

Kanun hükmünü icra şeklindeki hukuka uygunluk nedenindeki "kanun" deyimi normatif düzenlemeler içeren tüm yazılı hukuk kurallarını ifade etmektedir. ${ }^{[68]} \mathrm{Bu}$ nedenle, Anayasa'nın usulüne göre onaylanmış milletlerarası andlaşmaların üstünlüğü ve öncelikle uygulanması gerektiğini öngören 90/son maddesi gereğince, hekimin "kanunun" kendisine tanıdığı sınırlar içinde hareket edip etmediği belirlenirken, AİHS, bu sözleşmeyi yorumlamaya yetkili AİHM'in içtihatları ve usulüne uygun olarak yürürlüğe konmuş diğer ilgili uluslararası sözleşmeler öncelikli olarak dikkate alınmalıdır. ${ }^{[69]}$ Bu bağlamda, başka yazarlar tarafından da dile getirildiği üzere ${ }^{[70]}$ hekim için uygulanabilecek ve kusurluluğu ortadan kaldıran kanun hükmü, 5275 sayılı Ceza ve Güvenlik Tedbirlerinin İnfazı Hakkındaki Kanun'un 82. maddesinin birinci fikrası değildir. ${ }^{[1]}$ Söz konusu

[65] Özbek/Doğan/Bacaksız, s.280-281; Özgenç, s.330-331, 390.

[66] Toroslu, s.152.

[67] Özbek/Doğan/Bacaksız, s.280; Zafer, s.368.

[68] Özbek/Doğan/Bacaksız, s.283; Özgenç, s.330; Toroslu, s.152; Zafer, s.368.

[69] Özbek/Doğan/Bacaksız, s.285.

[70] Ömeroğlu, s.102.

[71] Madde 82- (1) Hükümlüler, hangi nedenle olursa olsun, kendilerine verilen yiyecek ve içecekleri sürekli olarak reddettikleri takdirde; bu hareketlerinin kötü sonuçları ile bırakacağı bedensel ve ruhsal hasarlar konusunda ceza infaz kurumu hekimince bilgilendirilirler. Psikososyal hizmet birimince de bu hareketlerinden vazgeçmeleri yolunda çalışmalar yapılır ve sonuç alınamaması hâlinde, beslenmelerine kurum hekimince belirlenen rejime göre uygun ortamda başlanır.

(2) Beslenmeyi reddederek açlık grevi veya ölüm orucunda bulunan hükümlülerden, birinci fikra gereğince alınan tedbirlere ve yapılan çalışmalara rağmen hayatî tehlikeye girdiği veya bilincinin bozulduğu hekim tarafından belirlenenler hakkında, isteklerine bakılmaksızın kurumda, olanak bulunmadığı takdirde derhâl hastaneye kaldırılmak suretiyle muayene ve teşhise yönelik tıbbî araştırma, tedavi ve 
hüküm, beslenmeyi reddederek açlık grevi yapan veya ölüm orucunda bulunan hükümlülerden hayatî tehlikesi olan veya bilincinin bozulduğu tespit edilen hükümlülere müdahale etme konusunda cezaevi hekimine yetki vermekte, hükümlünün rızasını aramamaktadır. Oysa 03.12. 2013 tarihli ve 5013 sayılı Kanunla onaylanması uygun görülen ve iç hukuk kuralı haline dönüşen Avrupa Konseyi Biyotıp Sözleşmesi'nin 5. maddesi "sağlık alanında herhangi bir müdahale, ilgili kişinin bu müdahaleye özgürce ve bilgilendirilmiş olarak muvafakat vermesinden sonra yapılabilir" hükmünü, 9.maddesi ise "müdahale sırasında isteğini açıklayabilecek durumda bulunmayan bir hastanın, tıbbî müdahale ile ilgili olarak önceden açıklamış olduğu istekleri göz önüne alınmalıdır” hükmünü içermektedir.

Yine söz konusu 82. madde, Ceza ve Güvenlik Tedbirlerinin İnfazı Hakkındaki Kanun'un 40., "Ceza İnfaz Kurumlarının Yönetimi ile Ceza ve Güvenlik Tedbirlerinin İnfazı Hakkında Tüzük” ün ${ }^{[72]} 79$. ve 80. maddeleriyle beraber değerlendirildiğinde, bu maddenin tıbbi zorunluluktan çok cezanın infazının gerçekleştirilebilmesi için hükümlünün beden bütünlügünü ve sağlığını koruma amacına yönelik olduğu ve söz konusu maddenin devletin hükümlünün bedeni üzerinde mutlak surette tasarruf yetkisi olduğu düşüncesine dayandığ görülmektedir. ${ }^{[73]}$ Çünkü Tüzüğün 79. maddesine göre, hükümlü, hapis cezasının yerine getirilmesine katlanma ve bu amaçla düzenlenen infaz rejimine uygun tutum ve davranışlar içinde bulunmakla yükümlüdür. Her ne amaçla olursa olsun, bilerek kendi yaşamını ve bedensel bütünlüğünü tehlikeye düşürecek eylemlere girişen hükümlü cezanın yerine getirilmesine katlanma yükümlülüğünü ihlâl etmiş sayılır. Bu bağlamda, söz konusu yükümlülüğün açlık grevi yapılarak ihlali CVGTİHK m. 40/2-g gereğince, hükümlünün bir aydan üç aya kadar süreyle kurumun kültürel ve spor etkinliklerine katılmaktan alıkonulması cezasıyla cezalandırılmaktadır. Bununla beraber, CVGTİHK'nın

beslenme gibi tedbirler, sağlık ve hayatları için tehlike oluşturmamak şartıyla uygulanır...

(4) Bu maddede öngörülen tedbirler, kurum hekiminin tavsiye ve yönetimi altında uygulanır. Ancak, kurum hekiminin zamanında müdahale edememesi veya gecikmesi hükümlü için hayatî tehlike doğurabilecek ise, bu tedbirlere ikinci fikrada belirtilen şartlar aranmaksızın başvurulur.

(5) Bu madde uyarınca hükümlülerin sağlıklarının korunması ve tedavilerine yönelik zorlayıcı tedbirler, onur kırıcı nitelikte olmamak şartıyla uygulanır.

[72] 06.04.2006 tarihli ve 26131 sayılı Resmi Gazete.

[73] Eren, s.137. 
82.maddesinde tedbirlerin onur kırıcı olmamasına vurgu yapılmasına rağmen, aşağıda açıklanacağı üzerine, AİHM içtihatlarında belirtilen tedbirin uygulanmasında kullanılan yöntemlerin onur kırıcı olmaması hususuna vurgu yapılmadığı, kurum hekimi dışında kalan kişilerin yapılacak müdahaleye ilişkin yetki ve sorumluluklarının tam olarak belirlenmediği görülmektedir.

$\mathrm{Bu}$ durumda, söz konusu 82. madde ve Tüzük hükümleri gereğince açlık grevi yapan bilinci açı bir hükümlüye hayati tehlikesi olduğu gerekçesiyle yapilacak müdahalenin, kanunun lafzi yorumundan hareketle ceza sorumluluğu doğurmayacağı düşünülse bile $\mathrm{e}^{[74]}$ hukuk sistemi ulusal ve uluslararası düzenlemeler ile bir bütün olarak ele alındığında, böyle bir müdahalenin hukuka uygun olmadığ ${ }^{[75]}$ ve ceza sorumluluğunu gerektirdiği düşüncesindeyiz. Çünkü aşağıda ayrıntılarıyla açıklanacağı üzere, açlık grevi yapan bir hükümlünün, bilgilendirmeye dayalı bilinçli rızası olmaksızın tedaviye tabi tutulması, AİHS'in 8. maddesinin birinci fikras1 anlamında hayat tarzına müdahale ve vücut bütünlüğünün dokunulmazlı̆̆ının ihlali sayılmaktadır. Bununla beraber, Avrupa Konseyi Biyotıp Sözleşmesinin 5. ve 9. maddeleri ile Hasta Hakları Yönetmeliğinden ${ }^{[76]}$ kaynaklanan bilgilendirmeye dayalı rızanın alınmaması halinde yapılacak müdahale, taraf devletin usuli yükümlülüklere aykırı davrandığı gerekçesiyle Sözleşme'nin 3. maddesinin ihlaline sebebiyet verecektir. Ayrıca müdahalenin icra şeklinden ve kullanılan araçlardan kaynaklanan sebeplerle Sözleşme'nin 3. maddesinde belirtilen asgari şiddet eşiğinin aşılması halinde, müdahalenin işkence, insanlık dışı ya da aşağılayıcı muamele sayılması mümkün olabilecektir. ${ }^{[77]}$ Nitekim AİHM'e göre, bilinci kapanan eylemci sağlık durumu hayatını tehdit etmesine rağmen her türlü müdahaleyi açıkça önceden reddetmiş ise bu iradeye saygı duyulması ve müdahale edilme-

[74] Önok’a göre (s.174), hayati tehlikesi olan mahkûma doktorun müdahale yükümlülüğünü yerine getirmemesi sebebiyle mahkûmun sağlığının bozulması veya ölmesi durumunda, yükümlülüğünü yerine getirmeyen doktorun kusurunun türüne göre, hareketsiz kalmasından ötürü ihmal suretiyle meydana gelecek yaralama veya ölümden sorumlu tutulması gerekmektedir. Feyzioğlu ve Soyaslan ise müdahale edilmemesi durumunda cezaevi hekimi ve diğer ilgililer için görevi ihmal suçunun oluşacağını belirtmektedir, Feyzioğlu s.167, Soyaslan s.279-280.

[75] Benzer görüş için bkz. Özgenç, s.376, 389.

[76] Hasta Hakları Yönetmeliği 01.08 .1998 tarihli ve 23420 sayılı Resmi Gazete, m. 15, 18, 22, 24, 25.

[77] Benzer görüş için bkz. Cengiz, s.437; Ömeroğlu s.104. 
mesi Sözleşmenin ihlali sayılmaz. ${ }^{[78]}$

Dolayısıyla, TCK'nın 24. ve Ceza ve Güvenlik Tedbirlerinin İnfazı Hakkındaki Kanun'un 82. maddesi, bilinci açık ve müdahaleyi reddeden eylemcilere müdahaleye izin verecek şekilde geniş yorumlanamaz. ${ }^{[7]}$ Bilinci kapalı eylemcilerin durumuna gelince, eğer eylemci, bilinç kaybı veya koma halinde müdahale edilip edilmemesi konusunda daha önceden herhangi bir irade beyanında bulunmamışsa hekim, ancak geri döndürülemez zararların doğmasını engellemek amacıyla, eylemcinin menfaati doğrultusunda tıbbi bir gerekliliğin tespit edilmesinin ardından, durumun gerektirdiği ölçüde zor kullanarak müdahalede bulunabilir. Nitekim bilinç kaybı veya koma halinde müdahale edilip edilmemesi konusunda daha önceden herhangi bir irade beyanında bulunmayan eylemci hakkında, AİHM, aşağıda da açılanacağı üzere, daha sonradan tıbbi bir gerekliliğin tespit edilmesinin ardından müdahalede bulunulmasını, tıbbi müdahalenin başvuranı aşağılama ve cezalandırma amacı taşımaması ve zorlayıcı yöntemlerin kullanılmaması şartıyla Sözleşmeye uygun bulmaktadır. ${ }^{[80]} \mathrm{Bu}$ halde de müdahale gerek uygulanma şekli gerekse kullanılan yöntemler bakımından ölçülü olmalıdır. Zorunlu olanın ötesinde güç ve yöntemler kullanılması halinde hukuka uygunluk nedeninde sınırın aşılması söz konusudur (TCK m.27).

Bilinci kapalı ve daha önceden irade beyanında bulunmamış eylemciler ile ilgili olarak hekimin hukuka uygunluk nedeni olarak "varsayılan

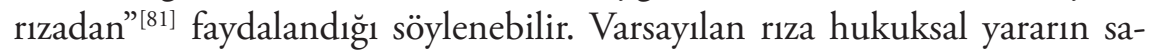
hibinin, örneğimizde eylemcinin, gerçek anlamda tedavi veya müdahaleyi onaylayan bir iradesinin mevcut olmadığı, ilgilinin bilinç kaybı halinde yapılacak işlemlere dair rızasının önceden zamanında alınamadığı, ancak ilgiliye sorulsaydı rıza göstereceğinin kabul edileceği hallerde söz konusu

[78] Horoz / Türkiye (Başvuru no. 1639/03), \$28, 31 Mart 2009.

[79] Özgenç'e göre, rıza aranmaksızın bir kimseye tıbbi müdahalede bulunulması ancak kamu sağlığını korumak gerekçesiyle ve ölçülülük ilkesinin ihlal edilmemesi koşuluyla mümkündür, s.389. Nitekim 1593 sayılı Umumi Hıfzıssıha Kanunu’nun 103. ve 107. maddeleri gereğince frengi, belsoğukluğu ve yumuşak şankr hastalıklarına tutulanların tedavisi zorunlu olup tedavi olunmaması halinde zor kullanılması, ilgilinin bir hastanede tecrit ve tedavi altına alınması mümkündür.

[80] İbrahim Ayhan Özgül / Türkiye, Kabul edilebilirlik hakkında karar, (Başvuru no.7715/02), 6 Mart 2007, s.7, 8.

[81] Öztürk/Erdem, s.268; Özbek/Doğan/Bacaksız s.316, 340; Soyaslan, Ceza Hukuku, s.366. Karşı görüşi için bkz. Özgenç, s.394. 
olur. Bunun için de eylemcinin bireysel yararları, istekleri, gereksinimleri ve değer yargıları göz önünde tutulmalıdır. ${ }^{[82]}$ Ancak özgür iradesiyle, yapay beslenmeyi reddeden ve bu kararının bilincinin kapanması sırasında da geçerli olacağını önceden belirten bir eylemcinin, önceden açıklamış olduğu iradesi kendisiyle ilgilenen hekim tarafından sonraki aşamalarda da dikkate alınmak zorundadır. ${ }^{[83]} \mathrm{Bu}$ tür varsayıma dayalı ve hukuka uygunluğu tartışmalı kararların önlenmesi için açlık grevi sırasında tedaviyi, yapay beslenmeyi ve müdahaleyi reddeden hükümlülere ilişkin olarak doktorların takip edeceği temel kuralların açık bir şekilde belirlenmesi, bilinç kaybı ve koma halinde eylemcinin önceden açıkladığı iradesinin geçerli olup olmadığının önceden kayıt altına alınması gerekmektedir.

Nitekim açlık grevi sırasında tedaviyi, yapay beslenmeyi ve müdahaleyi reddeden hükümlülere ilişkin olarak doktorların takip etmesi gereken temel ilkeler, Dünya Hekimler Birliği'nin Açlık Grevlerine İlişkin Bildirgesinde (The World Medical Association Declaration on Hunger Strikers) ortaya konmuştur. Söz konusu bildirge, Dünya Hekimler Birliği (The World Medical Association) tarafından Kasım 1991 tarihinde Malta'da düzenlenen 43. Dünya Tip Kongresi'nde (World Medical Assembly) kabul edilmiştir. Ardından Malta Bildirgesi'yle belirlenen ilkeler Eylül 1992'de Marbella İspanyåda toplanan 44. Dünya Tip Kongresi'nde revize edilmiş, Ekim 2006 tarihinde Güney Afrika’nın Pilansberg şehrinde toplanan 57. Dünya Tıp Kongresi'nde ise söz konusu ilkeler nihai şeklini almıştır.

AİHM'in açlık grevlerine müdahale konusunda verdiği Nevmerzhitsky ${ }^{[84]}$ ve Ceesay ${ }^{[85]}$ kararlarında da dikkate alınan Malta Bildirgesi'nin Giriş kısmında şu hususlar yer almaktadır.

"3-Açlık grevinde olan kişiyle hekim arasında da bir hekim hasta ilişkisi vardır; hekimin herhangi bir hastasıyla girdiği ilişkide üstlendiği yükümlülüklerde olduğu gibi, bu yükümlülüğün yerine getirilmesi öneriler ya da tedavi yoluyla yapabilir. Bu ilişki, hasta bazı tedavi ve müdahaleleri kabul etmese de sürebilir.

Bir hekim açlık grevcisinin bakımını üstlendiği andan itibaren o kişi hekimin hastası olur. Bu durum rızaya ve mahremiyete ilişkin yükümlülük

[82] Öztürk/Erdem, s.268.

[83] Cengiz, s.430.

[84] Nevmerzhitsky v. Ukraine (no. 54825/00), \$ 69, 5 April 2005.

[85] Ceesay v. Austria, (no.72126/14), \$ 69, 16 November 2017. 
ve sorumluluklar da dâhil olmak üzere, hasta-hekim ilişkisindeki tüm uygulama ve sorumluluklar için geçerlidir.

4-Müdahale etmek ya da etmemek hususunda son karar- hastanın iyiliğini ve çıkarlarım göz önünde bulundurmayan üçüncü şahısların herhangi bir müdahalesi olmaksızın- hekime bırakılmalıdır. Ancak hekim, hastanın tedaviyi veya koma durumunda yapay beslenmeyi reddetme ve dolayısıla ölüm riskini göze alma kararını kendisinin onaylayıp onaylamadığını hastaya açıkça belirtmelidir. Eğer hekim hastanın müdahale edilmemesi kararını onaylamıyorsa, bu durumda hastanın başka bir hekim tarafından takip edilmesi sağlanmalıdır."

Yine Malta Bildirgesinde yer alan temel ilkelerin "Yapay Beslenme" başlıklı 4. maddesine göre, "Eğer hastanın bilinci bulanır ve tek başına karar alamayacak durumda olursa ya da komaya girerse, hekim bu bildirgenin Giriş kısmının 4.maddesine uygun olarak ve açlı grevi sırasında daha önceden aldığı kararı her durumda dikkate alarak, tedaviye devam edip etmeme hususunda hastanın yüksek çıkarlarına uygun olduğunu düşündüğü kararı alma konusunda özgürdür.

Aynı ilkeler, Türk Tabipleri Birliği tarafından kabul edilen açlık grevinde hekim tutumuna ilişkin "Açlık Grevleri Sırasında Tibbi Etik İlkeler ve Bunun Pratik Yansımaları" başlıklı tutum belgesinde de belirtilmiştir. ${ }^{[86]}$ Buna göre;

"6-Hekim açlık grevindeki kişiyi her gün kontrol eder. Tıbbi takip formunu doldurur. Bu formda tıbbi bilgiler dışında hastanın kendi yazısıyla greve devam edip etmeme isteği ve bilinç kaybı durumunda tedaviyi kabul edip etmeme isteği mutlaka yer almalıdır. Bütün bu gelişmeler hekim tarafindan kaydedilir ve gizliliğinden hekim sorumludur.

9- Açlık grevcisinin bilinci bozulur ya da komaya girerse hekim açlık grevcisinin son kararına saygı göstererek tutum alacaktır. Bu çerçevede hastanın rızasına aykırı bir şekilde "zorla besleme" etik açıdan doğru değildir. $\mathrm{Bu}$ nedenle cezaevi hekimleri hastanın ister bilinci açık, isterse kapalı olsun olgunun takip formu ile müdahale onay/red belgesini bir başka sağllk merkezine nakil sırasında mutlaka ambulans hekimine alındı belgesi ile birlikte teslim etmelidir. Ambulans hekimi de ikinci basamak merkezinde-

[86] Erişim adresi: https://www.ttb.org.tr/aclik grev/index.html. Erişim tarihi: 30.03.2021. 
ki hekime bu belgeleri aynı şartlar alında ulaştırmalıdır. Belgelerin gizliliğinden hekimler sorumludur.

10- Bilinci açık olan açlık grevcisi beslenmeyi reddettiğinde bu kişiler hekimler tarafindan zorla beslenmeyecektir. Bunun aksi hem tıbbi etik, hem de hasta hakları açısından yanlış bir tutumdur."

Neticede hekimin hayat kurma yükümlülügünden kaynaklanan müdahale etme sorumluluğu, düşünceyi ifade özgürlüğünün sınırları içinde değerlendirilmesi gereken açlık grevini bir hak olmaktan çıkarmaz. Dolayısıyla, açlık grevine müdahalede mazeret nedeni olarak kabul edilebilecek olan ve TCK'nın 24. maddesinde yer alan kanun hükmünü yerine getirme şeklindeki hukuka uygunluk nedenindeki "kanun" deyimi ile bu hukuka uygunluk nedeninin maddi ve şekli şartları, Avrupa Konseyi Biyotıp Sözleşmesinden, AİHS’den, AİHM kararlarından ve Dünya Hekimler Birliğinin Açlık Grevlerine İlişkin Bildirgesinden bağımsız olarak sadece iç hukuka göre yorumlanamaz. ${ }^{[87]}$

Bu bağlamda, AİHM'in açlık grevlerine müdahale konusuna yaklaşımı, Mahkeme’nin yaşam ve ölüm hakkı kavramlarına getirdiği yorumlarla beraber aşağıda ayrıntılı olarak ele alınıp tartışılacaktır.

\section{III- AïHM IÇTIHATLARINDA YAŞAM VE ÖLÜM HAKKI VE AÇLIK GREVLERINE MÜDAHALE}

\section{A. AiHM'in Yaşam ve Ölüm Hakkına Yaklaşımı}

AİHS'in 2. maddesinde yer alan yaşam hakkının aynı zamanda ölme hakkını da içerip içermediği konusundaki tutumunu AİHM İngiltere'ye ilişkin verdiği Pretty kararında açıklamıştır. Diane Pretty 2001 yılında AİHM'e başvuru anında 43 yaşında olup kendisine 1999 yilında motor sinir hastalığı (MND) teşhisi konulmuştur. Söz konusu hastalık sinir hücrelerinde yıpranmaya, nefes alıp vermeyi sağlayan kaslar da dâhil olmak üzere kol ve bacak kaslarında güç kaybına, kasların iradi olarak hareket ettirilmesine yönelik yeteneğin kaybına neden olmaktadır. Zaman içinde nefes alıp vermeye yönelik kasların kasılma ve gevşeme yeteneğinin kay-

[87] Dolayısıyla Önok'un, zorla besleme uygulamasını Avrupa Konseyi Biyotıp Sözleşmesi'nden bağımsız olarak değerlendirip AİHS’e uygun bulan, doktorların Dünya Hekimler Birliği'nin Açlık Grevlerine İlişkin Bildirgesi’ne dayanarak müdahalede bulunmaktan kaçınamayacağını belirten görüşüne iştirak etmiyoruz, Önok, s.162, 184 . 
bedilmesi sebebiyle, ölüme neden olan söz konusu hastalığın herhangi bir tedavisi bulunmamaktadır. Hastalığı zaman içerisinde ilerleyen tüp ile beslenen ve boynundan aşağısı felç olan, kalan ömrü hafta veya ay ile ifade edilen Diane Pretty, acılarına ve hayatına intihar ederek son vermek istemektedir. Kendi başına intihar edemeyeceğinden, Diane Pretty, eşinin kendisine acısı bir ölüm sağlamak için gerekli ilacı vermesi ve intiharına yardım etmesi halinde, eşi hakkında ceza soruşturulması yapılmayacağına dair bir kararın verilmesi için İngiltere'de savcılık işlemlerinden ve ceza soruşturmasına ilişkin iş ve işlemlerden sorumlu olan makama (Director of Public Prosecutions (DPP)) başvurmuştur. Söz konusu makam şartlar ne kadar olağanüstü olursa olsun, böyle bir soruşturma veya kovuşturmadan muafiyet izninin verilemeyeceğini belirtmiştir. Bu karara karşı yerel mahkemede itiraz edilmiş, yerel mahkeme (divisional court) itirazı reddetmiş, bunun üzerine karar tarihinde İngiltere'de en yüksek mahkeme sıfatını haiz olan House of Lords nezdinde karara itiraz edilmiştir.

Diane Pretty dilekçesinde AİHS’in 2. maddesinin hayatı değil yaşama hakkını koruduğunu, kişilerin yaşamayı veya ölmeyi tercih etmelerinin özgür iradelerinin bir gereği olduğunu, bu özgürlüğün bir gereği olarak kişilerin tedaviyi kabul etmemeleri veya intihar etmeleri halinde herhangi bir yaptırımla karşılaşmadığını, ölme hakkının yaşam hakkının antitezi ve karşıtı (the antithesis of the right to life) olmadığını, yaşam hakkının doğal bir sonucu olduğunu (the corollary), devletin her iki durumu da korumaya yönelik pozitif yükümlülüklerinin bulunduğunu belirtmiştir. İngiltere'nin, kişilerin iradesine üstünlük tanımaması ve ölmeyi tercih etme hakkının olmadığını kabul etmesi halinde, AİHS'e taraf olan ve ötanaziye hâlihazırda izin veren ülkelerdeki durumun da Sözleşme’nin ihlali anlamına geleceğini ifade etmiştir. ${ }^{[88]}$

House of Lords bu konuya ilişkin kararında, AİHS kapsamında bazı özgürlüklerin, örneğin 11. maddedeki toplantı ve dernek kurma özgürlüğünün, derneğe üye olma hakkı yanında derneğe üye olmaya zorlanmama hakkını, 9. maddede yer alan düşünce, vicdan ve din özgürlüğünün, düşünceye sahip olma ve ifade etme yanında, düşünceye sahip olmama,

[88] The Queen on the Application of Mrs Dianne Pretty (Appellant) v. Director of Public Prosecutions (Respondent) and Secretary of State for the Home Department (Interested Party), 29 November 2001, [2001] UKHL 61, para. 4, para.5. Erişim adresi: https://publications.parliament.uk/pa/ld200102/ldjudgmt/jd011129/ pretty-1.htm. Erişim tarihi: 18.04.2021. 
değiştirme, ifade etmemeyi de içerdiğini, ancak insan hayatını üçüncü kişilerin müdahalesine karşı koruyan ve AİHS'in 2. maddesinde yer alan yaşam hakkının ölme hakkını da verdiği şeklinde bir sonucun, söz konusu maddenin yorumundan çıkarılamayacağını belirtmiştir. ${ }^{[89]}$ House of Lords'a göre, Diane Pretty'nin AİHS'in 8. maddesi gereğince özel hayatının bir parçası olan ölüm iradesine saygı gösterilmesini bekleme hakkı, tıbbi destekli intihar veya üçüncü kişilerin desteğiyle intihar olanağı sağlamak konusunda devlete pozitif yükümlülükler yüklememektedir. House of Lords'a göre, 8. madde hayat tarzına, hayatın nasıl sonlandıracağına dair iradeye saygı gösterilmesine imkân vermekle beraber, bu konuda devlete pozitif yükümlülükler yüklendiğine dair bir yorum, 8. maddenin aşırı geniş bir yorumu olacaktır. ${ }^{[0]}$

Konunun AİHM'e taşınması üzerine, Avrupa Konseyi Parlamenterler Meclisi'nin 1999 tarihli ve 1418 sayılı tavsiye kararına ${ }^{[91]}$ atıf yapan AİHM, Sözleşme'nin 2. maddesinin hem ölümle sonuçlanan hukuka aykırı eylemlerde bulunmaktan taraf devletleri alıkoyduğunu (öldürmeme-negatif yükümlülük), hem de taraf devletleri kendi egemenlik alanları içerisinde bulunan kimselerin hayatını korumak konusunda yetkilendirdiğini (koruma-pozitif yükümlülük) belirtmektedir. ${ }^{[92]}$ Dolayısıyla, AİHM' e göre, sınırları açıkça düzenlenmiş belli hallerde, insan hayatını üçüncü kişilerin suç teşkil eden eylemlerine karşı koruma konusunda 2. madde taraf devletlere pozitif yükümlülükler yüklemektedir. ${ }^{[93]}$ AİHM'e göre Sözleşme'nin 2. maddesinde düzenlenen yaşam hakkının olumsuz bir hakkı da kapsaması söz konusu değildir. Örneğin Sözleşme'nin 11. maddesinde düzenlenen toplant1 ve demek kurma özgürlüğ̈̈, derneğe üye olma hakkının yanında derneğe üye olmaya zorlanmama hakkını dolayısıyla tercih yapma olanağını getirirken, yaşam hakkına ilişkin maddenin lafzından bu hakkın olumsuz yönüne ilişkin olarak ölme hakkının da mevcut olduğu sonucunu çıkarmak mümkün değildir. Madde metni bu şekilde kaleme alınmamıştir. $^{[94]}$

[89] Dianne Pretty (Appellant) v. Director of Public Prosecutions, para.6.

[90] Dianne Pretty (Appellant) v. Director of Public Prosecutions, para.100.

[91] Recommendation 1418 (1999) of the Parliamentary Assembly of the Council of Europe.

[92] Pretty v. the United Kingdom, $\$ 38$. Aynı yorum için bkz. Lambert and Others v. France, $\$ 117$.

[93] Pretty v. the United Kingdom, $\$ 38$.

[94] Pretty v. the United Kingdom, $\$ 39$. 
AİHM'e göre, 2. madde hayatın kalitesi ve herhangi bir kimsenin kendi hayatı ile ilgili olarak ne yapmayı tercih ettiği hususuyla da ilgili değildir. Bu hususların, insan hayatı için devletin müdahale alanından çıkarılmayı gerektirecek derecede esaslı bir unsur olduğunun kabul edilmesi halinde Sözleşme'nin diğer maddelerinde ele alınması veya insan haklarına ilişkin diğer belgelerde düzenlenmesi mümkündür. Ancak kullanılan dil çarpıtılmaksızın, 2. madde ile ilgili olarak, maddenin yaşam hakkına taban tabana zıt olacak başka bir olumsuz hakkı, başka bir deyişle ölme hakkını da bahşettiği, ya da maddenin bu bağlamda kişilere yaşam yerine ölümü seçme konusunda bir özerklik tanıdığı, şeklinde yorumlanması mümkün değildir. ${ }^{[95]}$ Dolayısıyla, Avrupa Konseyi Parlamenterler Meclisi'nin 1999 tarihli ve 1418 sayılı tavsiye kararına uygun olarak, AİHM 2. maddenin kişilere gerek üçüncü kişinin yardımıyla ölüm, gerekse devletin sağlayacağı destekle ölüm konusunda, ölme hakkı tanıdığını söylemenin mümkün olmadığını belirtmektedir. ${ }^{[9]}$

Mahkemeye göre, vücut bütünlüğüne üçüncü bir kişinin veya kişinin bizzat kendisinin zarar vermesini mümkün kılan düzenlemelerin herhangi bir devlet tarafindan yapılması veya yapılmak istenmesi halinde, bu durum kaçınılmaz bir şekilde kişisel özgürlükler ile kamu yararının çatışıp çatı̧̧adığı hususunun denetlenmesini gerektirecektir. Böyle bir denetleme de ancak her olayın kendi şartlarında ve somut özelliklerine göre yapılabilecektir. Bununla beraber, Mahkeme'ye göre, zorlayıcı sebeplerle bazı devletlerin insan hayatının tıbbi destekli intihar yoluyla sona erdirilmesine izin veren uygulamalarının Sözleşme’nin 2. maddesine aykırı bulunmaması, Diane Pretty'e bu olanağı sağlamayan İngiltere'nin Sözleşme'nin 2. maddesinden kaynaklanan yükümlülüklerine aykırı davrandığı şeklinde yorumlanamaz. ${ }^{[97]}$

Ancak AİHM, gerek Pretty kararında gerekse ardından Lambert ve diğerleri kararında, ölüm sonucunun istenmediği ama öngörüldüğü hallerde, bir kimsenin bilinci yerinde iken yaşam süresini uzatacak tıbbi tedaviyi reddetmesi durumunda, ilgilinin bilinçli rızası veya aydınlatılmış onamı olmaksızın tedaviye tabi tutulmasını, Sözleşme'nin 8. maddesinin birinci fikrası anlamında, hayat tarzına müdahale ve vücut bütünlügünün dokunulmazlığının ihlali sayılabileceğini belirtmektedir. Dolayısıyla bir

[95] Pretty v. the United Kingdom, $\$ 39$.

[96] Pretty v. the United Kingdom, $\$ 40$.

[97] Pretty v. the United Kingdom, $\$ 41$. 
kimsenin hayat süresini uzatacak bir tedaviye rıza göstermemek suretiyle ölümü tercih etmesi, Sözleşme'nin 8. maddesi gereğince mümkündür. ${ }^{[98]}$ Mahkeme'ye göre, bir kimsenin hangi yöntemle ve hangi aşamada hayatının sona ereceğine karar vermesi, ilgilinin bu tür bir kararı alma konusunda irade serbestinin olması ve kararın sonuçlarını öngörerek karar vermesi halinde, Sözleşme'nin 8. maddesinde düzenlenen özel hayata ve aile hayatına saygı gösterilmesi hakkı kapsamında değerlendirilmelidir. ${ }^{[9]}$

Lambert ve diğerleri kararında özetlenen AİHM içtihatları incelendiğinde, ${ }^{[100]}$ tıbbi destekli intihara ilişkin Sanles Sanles, ${ }^{[101]}$ Pretty, ${ }^{[102]}$ Haas, ${ }^{[103]}$ Koch, ${ }^{[104]}$ kararları ile hayatın devamına veya sona ermesine neden olacak belli bir tedavinin yapılmasına veya durdurulmasına itiraza ilişkin Glass, ${ }^{[105]}$ Burke ${ }^{[106]}$ Ada Rossi ve diğerleri ${ }^{[107]}$ kararlarından sadece Glass ve Koch Kararı'nda, AİHM Sözleşme’nin 8. maddesinin ihlal edildiğine karar vermiştir. Bu bağlamda AİHM'in tıp, hukuk ve tıp etiği alanlarında karmaşık konuları kapsayan yaşam hakkına ilişkin başvuruları tartışmakta çekimser davrandığı söylenebilir. AİHM'e göre, tedavinin durdurulması gibi kararlarda, bu kararın iç hukuka ve Sözleşme'ye uygun olup olmadığının belirlenmesiyle, hastanın veya ilgilinin isteklerinin belirlenmesi yükümlülüğü, öncelikle taraf devletlere aittir. AİHM'in yetkisi ise sadece taraf devletlerin Sözleşme'nin 2. maddesinden kaynaklanan pozitif yükümlülüklerine riayet edip etmediklerini incelemekten ibarettir. ${ }^{[108]}$

Nitekim bu tür bir inceleme AİHM tarafından İsviçre devleti hakkında verilen Haas ${ }^{[109]}$ kararında yapılmıştır. Bu davada, bipolar rahatsızlığı bulunan ve iki kez intihara teşebbüs eden ve bunu başaramayan, Ernst G. Haas,

[98] Pretty v. the United Kingdom, $\$ 63$; Lambert and Others v. France, $₫ 180$.

[99] Haas v. Switzerland (no.31322/07), \$ 51, 20 January 2011.

[100] Lambert and Others v. France, $\$ 136-139$.

[101] Sanles Sanles v. Spain ((dec.) (no. 48335/99), 26 October 2000.

[102] Pretty v. the United Kingdom.

[103] Haas v. Switzerland.

[104] Koch v. Germany (no. 497/09), 19 July 2012.

[105] Glass v. the United Kingdom ((dec.) (no. 61827/00), 9 March 2004.

[106] Burke v. the United Kingdom ((dec.), (no. 19807/06), 11 July 2006.

[107] Ada Rossi and Others v. Italy (dec.) (nos. 55185/08, 55483/08, 55516/08, 55519/08, 56010/08, 56278/08 and 58424/08), 16 December 2008.

[108] Lambert and Others v. France, $\$ 181$.

[109] Haas v. Switzerland. 
acısız bir şekilde intihar etmek için ihtiyaç duyduğu sodium pentobarbital ilacını esaslı bir psikiyatrik değerlendirme ve reçete olmaksızın temin edemediğini ve İsviçre devletinin kendisine acısız ve başarısızlık riski bulunmayan bir yöntemle intihar etmesi için gerekli şartları sağlaması gerektiğini iddia etmiştir. Bunun üzerine, AİHM, bu tür bir talebin Sözleşme'nin 8. maddesinde yer alan özel hayata ve aile hayatına saygı gösterilmesi hakkı kapsamında karşılanıp karşılanamayacağını tartışmıştır. Mahkemeye göre, özel hayat kavramı oldukça geniş bir kavram olup kapsamlı ve eksiksiz bir tanımının yapılması mümkün değildir. Fakat özel hayat, insanın hem fiziki hem de psikolojik bütünlüğünü ifade etmekte olup yaşam hakkı ve özel hayata saygı gösterilmesi hakkının beraber değerlendirilmesi söz konusu olduğunda, Sözleşme bir bütün olarak ele alınmalıdır. Bu nedenle, kendi hayatını riske atan herhangi bir karar almak isteyen ya da alan, ancak bu kararının sonuçlarını irade serbestisi bulunmadığı için öngöremeyen ve dolayısıyla korunma ihtiyacı içinde olan kişileri devlet korumakla yükümlüdür. ${ }^{[110]}$ AİHM'e göre, bu tür çatışan çıkarlar ve haklar durumunda İsviçre devletinin, acısız ölüme imkân veren ilacı reçeteye ve kapsamlı psikiyatrik incelemeye bağlı olarak vermesi, kişilerin aceleyle bir karar almasının önüne geçmeyi, ilacın kötüye kullanımını önlemeyi, muhakeme yeteneği olmayan kimselerin ilaca ulaşmasını engelleyerek genel sağlığı korumayı, güvenliği sağlamayı ve suç işlenmesini önlemeyi amaçlamaktadır. ${ }^{[11]}$ Dolayısıyla, İsviçre devletinin insan onuruna yakışır bir intihar yöntemine erişimi kolaylaştırma konusunda pozitif yükümlülüğünün olduğu kabul edilse bile İsviçre devleti kendisine tanınan takdir yetkisi kapsamında hareket etmiş, yükümlülüklerini yerine getirmiş, 8. madde ihlal edilmemiştir. ${ }^{[12]}$

\section{B. AlHM'in Açlık Grevine Müdahale Konusuna Yaklaşımı}

Açlık grevlerinde hükümlülerin zorla yapay beslenmeye ve tedaviye tabi tutulup tutulamayacağına ilişkin temel yaklaşımını AİHM, Ukrayna aleyhine verdiği Nevmerzhitsky ${ }^{[13]}$ kararında ortaya koymuş ve 1992 yılında Avusturya hakkında verdiği Herczegfalvy ${ }^{[114]}$ kararına atıf yapmıştır. Mahkemeye göre, açlık grevi sırasında zor kullanarak eylemciyi beslemek, onur kırıcı ve aşağılayıcı bazı unsurlar içermektedir. Dolayısıyla, belli şartlar

[110] Haas v. Switzerland, $\$ 50,51,54$.

[111] Haas v. Switzerland, $\$ 56,58$.

[112] Haas v. Switzerland, $\$ 61$.

[113] Nevmerzhitsky v. Ukraine, $\$ \$ 93,94$.

[114] Herczegfalvy v. Austria (no. 10533/83), 24 September 1992. 
altında bu durumun, Sözleşme'nin 3. maddesiyle yasaklanan işkence, insanlık dışı ya da aşağılayıcı muamele boyutuna ulaşması mümkündür. Bir hükümlü veya tutuklunun açlık grevine başvurması ve sürdürmesi halinde, bu durum kaçınılmaz bir şekilde vücut bütünlüğünün dokunulmazlığ 1 hakkı ile taraf devletin Sözleşme'nin 2. maddesinden kaynaklanan hayatı korumaya dair pozitif yükümlülüğünün (koruma yükümlülüğ̈̈) çatışmasına sebebiyet verecektir. Böyle bir çatışma durumunun nasıl çözümleneceği konusunda ise Sözleşme herhangi bir çözüm yöntemi sunmamaktadır. ${ }^{[15]}$

Bu bağlamda, akıl sağlığı yerinde olmayan hükümlünün akıl hastanesinde zorla tedavi altına alınmasının ardından bu durumu protesto etmek için başlattığı açlık grevinde yapay beslenmeye tabi tutulmasını Sözleşme'nin 3. maddesine aykırı bulmayan Herczegfalvy kararına atıf yapan AİHM'e göre, tıp biliminin kabul edilmiş yerleşik prensipleri tarafından tedavi kapsamında olduğu kabul edilen ve uygulanması gerekli görülen bir önlemin, kural olarak insanlık dışı veya aşağılayıcı olduğu söylenemez. Aynı kural, beslenmeyi kasten reddeden bir hükümlünün ya da tutuklunun hayatının kurtarılması amacıyla zor kullanılması, yapay beslenmeye tabi tutulması hali için de geçerlidir. ${ }^{[16]}$ Ancak bu hususta,

a) Tibbi müdahalenin gerekli ve zorunlu olduğu ikna edici bir şekilde (convincingly) ortaya konmalı,

b) İç hukukta kararın alınması sürecinde uyulması gereken usul kurallarına ilişkin garantilere uyulmalı, ilgiliye gerekli bilgilendirmeler yapılmalı, itiraz hakkı verilmeli, zorla besleme kararı ve bu karara yapılacak itiraz yargısal denetime tabi tutulabilmeli,

c) Nihayetinde, zor kullanarak besleme kararının uygulanma tarzı Sözleşme'nin 3. maddesinde belirtilen asgari şiddet eşiğini geçmemeli, işkence, insanlık dışı ya da aşağılayıcı muamele boyutuna ulaşmamalıdir. ${ }^{[117]}$

Sözleşme'nin 3.maddesi anlamında bir muamelenin aşağılayıcı olup olmadığının belirlenmesinde, muamelenin aşağılama amacı güdüp güt-

[115] Nevmerzhitsky v. Ukraine, $\$ 93$. Ayrıca bkz. X v. Germany (1984) 7 EHRR 152; Ciorap v. Moldova (no.12066/02), \$76, 19 June 2007.

[116] Herczegfalvy v. Austria, $\$ 82$, 83; Nevmerzhitsky v. Ukraine, $\$ 94$; Ciorap v. Moldova, $₫ 77$.

[117] Nevmerzhitsky v. Ukraine, $\$ 94$; Ciorap v. Moldova, $\$ 77$. 
mediğinin ve ilgilinin kişiliği üzerinde 3.madde ile bağdaşmaz bir şekilde olumsuz etki ya da sonuçlar bırakıp bırakmadığının göz önüne alınması gerekmektedir. Ancak aşağılama kastının bulunmaması tek başına ihlalin mevcut olmadığına gerekçe teşkil edemeyecektir. ${ }^{[118]}$ Yine Sözleşme'nin 3. maddesi, her bir hükümlü ve tutuklunun insan onuruna saygılı koşullarda tutulmasını öngörmekte, hükümlü ve tutuklular hakkında alınacak her bir önlemin gerek uygulanma şekli gerekse kullanılan yöntemler bakımından (the manner and method of the execution), hürriyetten yoksun kalmanın doğasında kaçınılmaz bir şekilde mevcut olan ıstırabın ötesine geçecek derecede, hükümlü veya tutuklu üzerinde sıkıntıya ya da güçlüğe neden olmaması gerektiğini belirtmektedir. ${ }^{[19]}$

Yine bir önlem veya tedbirin Sözleşme'nin 3. maddesinde belirtilen asgari şiddet eşiğini geçip geçmediği, işkence, insanlık dışı ya da aşağılayıcı muamele boyutuna ulaşıp ulaşmadığı, muamele veya yaptırımın süresi, ruhsal ve fiziksel etkileri gibi somut olayın tüm koşullarına, kimi durumlarda da ilgilinin yaşına, cinsiyetine ve sağ lık durumuna bağlı olarak değerlendirilmelidir. ${ }^{[120]}$

Bu prensipler ışığında AİHM Nevmerzhitsky Kararı'nda, hükümlünün sağlığında hayati tehlike yaratan bir bozulma olduğunu ve zor kullanarak beslemenin zorunlu ve gerekli olduğunu ikna edici bir şekilde ortaya koyan herhangi bir tıbbi raporun sunulmadığını, zorla besleme sırasında hükümlünün yüksek çıkarlarına öncelik verildiğinin ve buna uygun davranıldığının söylenemeyeceğini belirtmiş̧ir. Ardından AİHM, zorla besleme sırasında hükümlünün kelepçelenmesi, ağız genişletici aletler kullanılması, plastik bir tüpün hükümlünün yemek borusuna indirilmesi, hükümlünün direnmesine karşı güç kullanılması uygulamaları ve söz konusu uygulamaların şiddeti göz önüne alındığında, herhangi bir tıbbi zorunluluğun ikna edici bir şekilde ortaya konamaması sebebiyle, hükümlünün tabi tutulduğu zor kullanarak besleme uygulamasının keyfi olduğu ve Sözleşme’nin 3. maddesi bağlamında işkence sayılması gerektiğine karar vermiştir. ${ }^{[121]}$

[118] Ilaşcu and Others v. Moldova and Russia (no. 48787/99), \$ 427, 8 July 2004.

[119] Ilaşcu and Others v. Moldova and Russia, $\$$ 428; Kudla v. Poland [GC], (no. 30210/96), $\$ \$ 92-94,26$ October 2000; Mouisel v France (no. 67263/01), $\$ 40$, 14 November 2002; Ciorap v. Moldova, $\$ 64$.

[120] Ciorap v. Moldova, $\$ 63$.

[121] Nevmerzhitsky v. Ukraine, $\$ \$ 95-99$. 
Aynı temel prensipler ışığında Moldova'ya ilişkin Ciorap Kararı'nda da AİHM, ihlal kararı vermiştir. Bu kararda AİHM, açlık grevi yapan başvuranın zorla beslenmeye tabi tutulmasının, başvuranın hayatını korumaktan çok cezaevi şartlarını açlık grevi yoluyla protesto etmeye yönelik eylemin sonlandırılması amacı güttüğünü, ${ }^{[122]}$ zorla beslenmeye tabi tutulacak kadar sağlığının bozulduğu iddia edilen başvuranın mahkeme huzuruna çıkabilecek kadar sağlıklı olduğu gerekçesiyle duruşmalara katılmasının sağlandığını, bir kimsenin sağlığının aynı anda hem iyi hem de kötü olmasının tuhaf olduğunu, ${ }^{[123]}$ zorla besleme uygulamasına neden başlandığını ortaya koyacak ve bu uygulamayı haklı kılacak hiçbir tıbbi delil veya test sonucunun dosyada bulunmadığını, dahası cezaevi kayıtlarında başvuranın sağlık durumunun "iyi” veya "kısmen iyi" şeklinde raporlandığını, bunun zorla beslenmeyi gerektirecek hayati tehlike kavramıyla bağdaşmadığını ${ }^{[124]}$ zorla beslemeye ilişkin herhangi bir gerekçenin başvurana sunulmadığı ve bu konudaki usul kurallarına uyulmadığını, ${ }^{[125]}$ zor kullanarak beslemenin zorunlu ve gerekli olduğunu ikna edici bir şekilde ortaya koyan herhangi bir tıbbi raporun sunulmadığı bir durumda hükümlünün yüksek çıkarlarına öncelik verildiğinin ve buna uygun davranıldığının söylenemeyeceğini, bu şartlarda zorla besleme uygulamasının tıbbi bir zorunluluktan çok ilgilinin açlık grevi yaparak cezaevi koşullarını protesto etmesini önlemek ve cesaretini kırmak amacı güttüğünü, ortada tıbbi bir zorunluluktan bahsedilemeyeceğini belirtmiştir. ${ }^{[126]}$

Nihayetinde, zor kullanarak besleme kararının uygulanma tarzına ilişkin olarak Ciorap Kararı'nda Mahkeme ayrıca, başvuranın direnmemesine rağmen kelepçelendiğini, dilinin maşayla dışarı çıkarılması için zor kullanıldığını, bunun başvuranın dilinin ve ağzının kanamasına, dişinin kırılmasına yol açtığını ${ }^{[127]}$ zorla beslemeye neden olan durumların açıklanmayarak zorla besleme sırasında vücuda verilen besin miktarının ve içeriğinin gözlemlenmediğini veya sadece bazen gözlemlendiğini, ${ }^{[128]}$ başvuranın serum takılarak damar yoluyla beslenme ve gerekli serum setlerini

[122] Ciorap v. Moldova, $\$ 79$.

[123] Ciorap v. Moldova, $\$ 80$.

[124] Ciorap v. Moldova, $\$ 81$.

[125] Ciorap v. Moldova, $\$ 82$.

[126] Ciorap v. Moldova, $\$ 83$.

[127] Ciorap v. Moldova, $\$ 85$.

[128] Ciorap v. Moldova, $₫ 86$. 
ailesi aracilığıyla temin etme taleplerinin dikkate alınmadığını, zorla beslemeye alternatif olabilecek daha az müdahaleyi gerektiren yöntemlerin mevcut olmasına ve başvuranın talebine rağmen uygulanmadığını, ${ }^{[129]}$ bu durumda kullanılan yöntemin zorunlu olanın ötesinde aşağılayıcı ve acı verici olduğunu, bu nedenlerle söz konusu müdahalenin Nevmerzhitsky Kararı'nda hükmedildiği gibi, sadece işkence olarak değerlendirilebileceğini ve Sözleşme'nin 3. maddesinin ihlal edildiğini belirtmiştir. ${ }^{[130]}$

Yine hükümlü ve tutukluların tabi tutulacağı muamele konusunda AİHM, Türkiye’ye ilişkin Özgül Kararı'nda, Sözleşme’nin 3. maddesinin taraf devletleri, özgürlügünden yoksun bırakılan kişilerin fiziki bütünlügünü gerekli tıbbi tedaviyi sağlayarak korumakla yükümlü kıldığını hatırlatmaktadır. Dolayısıyla hükümlü ve tutuklular, gereklilikleri hiçbir şekilde askıya alınamayan 3. madde ile korunmaktadır. ${ }^{[131]}$ Ardından Nevmerzhitsky ve Herczegfalvy Kararı'nda belirttiği "tıp biliminin kabul edilmiş yerleşik prensiplerine göre, tedavi kapsamında olduğu kabul edilen ve uygulanması gerekli görülen bir önlemin, kural olarak insanlık dışı veya aşağılayıcı olduğu söylenemez" kuralını hatırlatan Mahkeme, doktorların, hükümlünün sağlık durumunun tatmin edici olması sebebiyle açlık grevi konusunda isteğine saygı duymaları ve ancak geri döndürülemez zararların doğmasını engellemek amacıyla başvuranın menfaati doğrultusunda tıbbi bir gerekliliğin tespit edilmesinin ardından müdahalede bulunmasını, tıbbi müdahalenin başvuranı aşağılama ve cezalandırma amacı taşımamasını, zorlayıcı yöntemlerin kullanılmamasını gerekçe göstererek Sözleşme’ye uygun bulmuştur. ${ }^{[132]}$

Ancak bu karara konu olayda İbrahim Ayhan Özgül'ün açlık grevine başlamadan önce tedaviyi hiç bir şart ve koşulda kabul etmediğine dair açı bir beyanının olup olmadığına dair herhangi bir tartışmaya veya açıklamaya kararda yer verilmemiştir. Bu kapsamda kısmi bir tartışmayı AİHM Horoz $^{[133]}$ Kararı'nda yapmıştır. Söz konusu karara ilişkin olayda, 1966 doğumlu Muharrem Horoz, 3 Ağustos 1999 tarihinde polis operasyonunun ardından İstanbul'da yakalanmış, işlediği terör eylemleri sebebiyle tutuk-

[129] Ciorap v. Moldova, $\$ 87$.

[130] Ciorap v. Moldova, $\$ \$ 88,89$.

[131] İbrahim Ayhan Özgül / Türkiye, Kabul edilebilirlik hakkında karar, s.7, Ayrıca bkz. Mouisel v France, $\$ 40$.

[132] İbrahim Ayhan Özgül / Türkiye, s.7, 8.

[133] Horoz / Türkiye. 
lanmış, Kandıra Cezaevi’nde tutuklu bulunduğu sırada koğuş sisteminden bir ile üç kişilik yaşam alanlarına geçişi öngören $\mathrm{F}$ tipi cezaevlerini protesto için açlık grevine başlamış ve bu eylemini ölüm orucuna çevirmiştir. Eylem süresince sadece şekerli su ve vitamin almıştır. Muharrem Horoz, 30 Nisan 2001-25 Temmuz 2001 tarihleri arasinda, cezaevi doktoru tarafindan on bir defa muayene edilmiştir. İlgiliye birçok defa vitamin verilmiştir. $12 \mathrm{Ha}-$ ziran 2001 tarihinde muayene edilmek üzere Kocaeli Devlet Hastanesi'nin Nöroloji Servisi'ne, 14 Haziran 2001, 13 Temmuz 2001 ve 19 Temmuz 2001 tarihlerinde aynı hastanenin Acil Servisi'ne sevk edilmiştir. Muharrem Horoz yeniden canlandırıldığında her türlü müdahaleyi reddetmiş; ardından kendi hücresine gönderilmiştir. Muharrem Horoz, 29 Haziran 2001 ve 25 Temmuz 2001 tarihlerinde aynı hastanenin Nöroloji ve İç Hastalıkları Servisi'ne sevk edilmiştir. 27 Temmuz 2001 tarihinde bilincini tamamen kaybetmesi sebebiyle, Muharrem Horoz bir kez daha hastaneye yatırılmıştır. Adli Tip Kurumu, 30 Temmuz 2001 tarihli raporunda, "beslenme yetersizliğine bağlı terminal yetmezlik" teşhisi koymuş ve $\mathrm{Mu}$ harrem Horoz' un sağlık durumunun cezaevi koşullarıyla uyumlu olmadığı kanısına vararak altı ay süreyle serbest bırakılmasını tavsiye etmiştir. Devlet Güvenlik Mahkemesi ise 1 Ağustos 2001 tarihinde 1412 sayılı mülga Ceza Muhakemesi Usulü Kanunu'nun (CMUK) 399. maddesinin "tutuklu" kişilere kıyasen uygulanamayacağı, bu maddenin "hükümlüler" için öngörüldüğü ve Muharrem Horoz’un tedavisinin bir devlet hastanesinin cezaevi koğuşunda sağlanabileceği gerekçesiyle, serbest bırakılma talebini reddetmiştir. Muharrem Horoz, 3 Ağustos 2001 tarihinde, 27 Temmuz 2001 tarihinden itibaren tutulduğu Kocaeli Devlet Hastanesi'nin cezaevi koğuşunda hayatını kaybetmiştir. Muharrem Horoz'un annesi, oğlunun Adli Tip Kurumu raporuna rağmen serbest bırakılmaması ve cezaevinde ölmesi sebebiyle, Sözleşme'nin 2. maddesinde yer alan yaşam hakkının ihlal edildiği gerekçesiyle AİHM'e başvurmuştur.

AİHM Horoz Kararı'nda, öncelikle Matencio ${ }^{[134]}$ Mouisel $^{[135]}$ ve Balye$m e z^{[136]}$ kararlarında belirtilen, Sözleşme'nin sağlık nedenleriyle bir tutuklunun serbest bırakılmasına ilişkin hükümler içermediği hususunu hatırlatmıştır. Ancak, AİHM, tutukluların sağlığını koruma konusunda taraf devletlere düssen yükümlülüklerin yanında, tutukluda daha sonra doğal

[134] Matencio v. France, (no. 58749/00), \$ 78, 15 January 2004.

[135] Mouisel v. France, $\$ \$ 37,38,40$.

[136] Balyemez / Türkiye (Başvuru no. 32495/03) \$\$ 84-87, 22 Aralık 2005. 
yollardan ortaya çıkan bedensel veya ruhsal bir rahatsızlığın, tutuklama koşullarının tabiatından kaynaklanandan daha fazla bir acıya sebep olması veya tutukluluk koşulları sebebiyle artması ya da artma ihtimalinin bulunması halinde, bu durumun Sözleşme'nin 3.maddesi kapsamında insanlık dışı ve aşağılayıcı bir muamele sayılabileceğini belirtmiştir. ${ }^{[137]}$ Bununla beraber, AİHM tedavinin durdurulması gibi kararlarda, bu kararın iç hukuka ve Sözleşme’ye uygun olup olmadığının belirlenmesi yükümlülüğünün öncelikle taraf devletlere ait olduğunu, kendisini ulusal makamların yerine koyamayacağını, bu konuda sadece taraf devletlerin Sözleşme'nin 2. maddesinden kaynaklanan pozitif yükümlülüklerine riayet edip etmediklerini incelemekle yetkili olduğunu belirtmiştir. ${ }^{[138]}$ Ardından Mahkeme açıkça, yetkili makamların, "Muharrem Horoz'un sağlık durumunun hayatını tehdit etmesine rağmen, ilgilinin her türlü müdahaleyi açıkça reddetmesini kabul etmekle de eleştirilemeyecekleri kanısına vardığını" ${ }^{[139]}$ ve Sözleşme’nin 2. maddesinin ihlal edilmediğini belirtmiştir. Yine Muharrem Horoz'un tutukluluk koşullarının Sözleşme'nin 3. maddesi anlamında, tek başına insanlık dışı veya aşağılayıcı muamele teşkil ettiğine inanılmasını sağlayacak ciddi ve kesin gerekçelerin bulunmadığını belirtmiştir. ${ }^{[140]}$ Ancak bu Karar 5’e karşı 2 oyla oyçokluğuyla alınmıştır. Karşı oy gerekçesinde, Adli Tip Kurumu'nun 30 Temmuz 2001 tarihli raporunda, "beslenme yetersizliğine bağlı terminal yetmezlik” teşhisi koyduğunu ve Muharrem Horoz’un sağlık durumunun cezaevi koşullarıyla uyumlu olmadığı kanısına varıp serbest bırakılmasını tavsiye ettiğini, tıbbi bir kurumun düzenlediği bu türden bir rapor karşısında, cezaevinde gerekli tıbbi tedavilerin uygulanabileceğine ilişkin verilen güvencelerin dikkate alınamayacağı ifade edilmiştir. Karşı oy kullanan hâkimler, çoğunluğun kabul ettiğinin aksine, ilgilinin Adli Tıp Kurumu raporuna dayanılarak serbest bırakılmasının, yalnızca "arzu edilir” olmadığını, aynı zamanda Sözleşme’nin 2. maddesiyle güvence altına alınan yaşamı koruma hakkının mutlak gerekliliği bakımından zorunlu olduğunu, bu nedenle 2. maddenin ihlal edildiğini belirtmişlerdir.

[137] Horoz / Türkiye, $\$ 22$.

[138] Horoz / Türkiye, $\$ 28$. Bkz. ayrıca Lambert and Others v. France, $\$ 181$.

[139] Horoz / Türkiye, $\$ 28$.

[140] Horoz / Türkiye, $\$ 31$. 


\section{SONUÇ}

Buraya kadar aktardığımız AİHM içtihatlarına dayalı açıklamaların da gösterdiği üzere, hekimin hayat kurtarma yükümlülügünden kaynaklanan müdahale etme sorumluluğu, düşünceyi ifade özgürlüğünün sınırları içinde değerlendirilmesi gereken açlık grevini bir hak olmaktan çıkarmaz. Dolayısıyla, açlık grevine müdahale edilmesini hukuka uygun hale getirebilecek olan ve TCK'nın 24. maddesinde "kanun hükmünü yerine getirme" şeklinde ifade edilen hukuka uygunluk nedenindeki "kanun" deyimiyle, bu hukuka uygunluk nedeninin maddi ve şekli şartları, açlık grevine ilişkin doğrudan ve dolaylı düzenlemeler içeren Avrupa Konseyi Biyotıp Sözleşmesi'nden, AİHS'den, AİHM kararlarından ve Dünya Hekimler Birliği' nin Açlık Grevlerine İlişkin Bildirgesi'nden bağımsız olarak sadece iç hukuka göre belirlenemez.

Yine tıp, hukuk ve tıp etiği alanlarında karmaşık konuları kapsayan yaşam hakkı ve açlık grevine müdahale hususu, kaçınılmaz bir şekilde hükümlü veya tutuklunun vücut bütünlügünün dokunulmazlığı ile taraf devletin Sözleşme'nin 2. maddesinden kaynaklanan hayatı korumaya dair pozitif yükümlülüğünün (koruma yükümlülüğü) çatışmasına sebebiyet verecektir. Böyle bir çatışma durumunun nasıl çözümleneceği konusunda ise AİHS herhangi bir çözüm yöntemi sunmamaktadır. ${ }^{[141]}$

Bu nedenle, AİHM, Sözleşme'nin 2. maddesi kapsamında yer alan yaşam hakkına ilişkin konuları tartışmakta çekimser davranmakta, açlık grevine zor kullanarak yapay beslenme yöntemiyle müdahale etme konusunu 2.madde kapsamında değil Sözleşme'nin işkence yasağına ilişkin 3. maddesi ile özel hayata ve aile hayatına saygı gösterilmesi hakkına ilişkin 8 . maddesi kapsamında değerlendirmeyi tercih etmektedir. Bu bağlamda, bir kimsenin hayat süresini uzatacak bir tedaviye rıza göstermemek suretiyle ölümü tercih etmesi, Sözleşme'nin 8 . maddesi gereğince mümkündür. ${ }^{[142]}$

Mahkemeye göre, bir kimsenin hangi yöntemle ve hangi aşamada hayatının sona ereceğine karar vermesi, ilgilinin bu tür bir kararı alma konusunda irade serbestinin olması ve kararın sonuçlarını öngörerek karar vermesi halinde, Sözleşme'nin 8. maddesinde düzenlenen özel hayata ve aile hayatına saygı gösterilmesi hakkı kapsamında değerlendirilmelidir.

[141] Nevmerzhitsky v. Ukraine, $\$ 93$. Ayrica bkz. X v. Germany; Ciorap v. Moldova, $\$$ 76.

[142] Pretty v. the United Kingdom, $\$ 63$; Lambert and Others v. France, $\$ 180$. 
AİHM, bir kimsenin bilinci yerinde iken yaşam süresini uzatacak tıbbi tedaviyi reddetmesi durumunda, ilgilinin bilinçli rızası veya aydınlatılmış onamı olmaksızın tedaviye tabi tutulmasını, Sözleşme’nin 8. maddesinin birinci fıkrası anlamında hayat tarzına müdahale ve vücut bütünlügünün dokunulmazlığının ihlali sayılabileceğini belirtmektedir.

Yine açlık grevine devletin pozitif koruma yükümlülügünden kaynaklanan sorumlulukları nedeniyle müdahalesi, müdahalenin Sözleşme'nin 3. maddesiyle yasaklanan işkence, insanlık dışı ya da aşağılayıcı muamele boyutuna ulaşmaması şartıyla mümkündür. Bir hükümlü ya da tutuklunun sağlık durumu hayatını tehdit eder dereceye ulaşmasına rağmen ilgilinin her türlü müdahaleyi açıkça reddetmesi ve açlık grevine devam etmesi halinde, bu durumu kabul edip müdahalede bulunmayan devletlerin de AİHM'e göre eleştirilmesi mümkün değildir. Yapay besleme yoluyla müdahale yönteminin tercih edilmesi halinde ise tıbbi müdahalenin gerekli ve zorunlu olduğu ikna edici bir şekilde (convincingly) ortaya konmalı, iç hukukta kararın alınması sürecinde uyulması gereken usul kurallarına ilişkin garantilere uyulmalı, ilgiliye gerekli bilgilendirmeler yapılmalı, zorla besleme kararı ve bu karara itiraz yargisal denetime tabi tutulabilmeli, nihayetinde, zor kullanarak besleme kararının uygulanma tarzı ve bunun için kullanılan araçlar, Sözleşme'nin 3. maddesinde belirtilen asgari şiddet eşiğini geçmemeli, işkence, insanlık dışı ya da aşağılayıcı muamele boyutuna ulaşmamalıdır. ${ }^{[143]}$ Ancak özgür iradesiyle, yapay beslenmeyi reddeden ve bu kararının bilincinin kapanması sırasında da geçerli olacağını önceden belirten bir eylemcinin, önceden açılamış olduğu iradesi kendisiyle ilgilenen hekim tarafından sonraki aşamalarda da dikkate alınmak zorundadır.

Bu itibarla, iç hukukta yapılan açlık grevinin belli aşamadan sonra hukuka aykırı olduğu dolayısıyla bu aşamadan itibaren müdahale edilmesinin meşru olduğu ya da hiç kimsenin ölme hakkının olmadığı, bu nedenle açlık grevine müdahale edilmesi gerektiği tartışmaları sığ ve yüzeyseldir. Anayasa'nın 26., Türk Medeni Kanunu'nun 23. ve 24. maddeleri göz önüne alındığında bir kimseyi gıda ve sıvı almaya mecbur bırakan bir norm olmadığı gibi bir kimsenin kendisine eziyet etmesini engelleyen norm da yoktur. Dolayısıyla, aç kalmak suretiyle besin almaya ve yapay beslenmeye direnme, arzu edilmeyen, kişisel olarak hiçbir şekilde desteklemeyeceğimiz, ancak yukarıda açıkladığımız ulusal ve uluslararası düzenlemeler ışığında baştan itibaren hukuka uygun bir ifade biçimidir. Nitekim ifade

[143] Nevmerzhitsky v. Ukraine, $\$ 94$; Ciorap v. Moldova, $₫ 77$. 
özgürlüğü kapsamında AİHS’ in 10. maddesi, ifade edilen fikir ve bilgilerin yalnızca içeriğini değil aynı zamanda aktarım şeklini de korumaktadır. $\mathrm{Bu}$ bağlamda, insanların düşüncelerini, fikirlerini ve eleştirilerini genel yöntemlere kıyasla daha az aşikâr olan açlık grevi gibi yöntem ve araçlarla aktarmaları ve ifade etmeleri durumu da Sözleşme'nin 10. maddesi kapsamında garanti altına alınmıştır. ${ }^{[144]} \mathrm{Bu}$ nedenle, bir hakkın yine hukuk düzenince izin verilen yöntemler ile talep edilmesi gerektiği, bu nedenle hak arama hürriyetinin sadece idareye ve yasama organına dilekçe verme ve yargı mercilerine başvurmak yöntemlerini kapsadığı, dolayısıyla amacı her ne olursa olsun açlık grevlerinde kullanılan yöntemin meşru olmadığ ve hak arama hürriyeti kapsamında değerlendirilemeyeceği düşüncesine ${ }^{[145]}$ katılmak mümkün gözükmemektedir. Ancak, Anayasa Mahkemesi ceza ve infaz kurumlarında hükümlü ve tutuklular tarafından yapılabilecek açlık grevlerini ifade özgürlügü kapsamında değerlendirmemekte, bir disiplin sorunu olarak görmekte, cezanın yerine getirilmesine katlanma yükümlülügünün ihlâli saymakta, disiplin cezasıyla cezalandırılmasını hukuka uygun bulmaktadır.

Fakat açlık grevleri ifade özgürlüğünün sınırları kapsamında ele alınmalı ve değerlendirilmelidir. Bu nedenle, hayati risk aşamasına gelmiş açlık grevine müdahale edilip edilmeyeceği sorunu meşruiyetten çok ceza sorumluluğunun doğup doğmadığı ya da mazeret nedeninin bulunup bulunmadığı sorunudur. Bu durumda, açlık grevlerine veya ölüm oruçlarına hangi hallerde müdahale edilebileceği hangi hallerde sınırın aşılmış sayılması gerektiği, hukuka uygunluk sebepleri açısından ele alınıp incelenirken, hukuk düzeni bir bütün olarak ele alınmalıdır. Hukuka uygunluk nedeninin maddi ve şekli şartları, Avrupa Konseyi Biyotıp Sözleşmesi, AİHS ve AİHM kararları ve Dünya Hekimler Birliği’ nin Açlık Grevlerine İlişkin Bildirgesi dikkate alınarak belirlenmelidir. Sadece iç hukuka göre yorum yapılması, kendi özgür iradesiyle açlık grevi yapan, grev sırasında yapay beslenmeyi ve müdahaleyi açıç̧a reddeden ve bu kararının bilincinin kapanması sırasında da geçerli olacağını önceden belirten hükümlü veya tutuklulara, CVGTİHK'nın 82. maddesi gerekçe gösterilerek zor kullanılarak tıbbi müdahalede bulunulması, kanaatimizce, kanunun lafzı aksini gerektirse de hem cezai hem de hukuki açıdan sorumluluğun doğmasina sebebiyet verebilecektir.

[144] Murat Vural / Türkiye, $\$ 44$; Oberschlick v. Austria, $\$ 57$.

[145] Taşkın, s.555-556. 


\section{KAYNAKÇA}

Akal, Cemal Bali, "İspanyàda Açlık Grevlerinin Doğurduğu Sorunlar" Argumentum, Şubat 1992, Y.2, S.19, s. 291-295.

Akıncı, Şahin "İrade Muhtariyeti İlkesi ve Şahsiyet Hakları Açısından Ötanazi, Açlık Grevi ve Ölüm Orucu”, Selçuk Üniversitesi Hukuk Fakültesi Dergisi, 1998, C.6, S.1-2, Prof. Süleyman Arslan’a Armağan, s.733-766.

Aşıkoğlu, Eda Demirsoy, "Kişi Dokunulmazlığı Hakkı Bağlamında Riza Olmaksızın Yapılan Tibbi Müdahaleler", TAAD, 2018, Y.9, S.35, s.319-343.

Beşiri, Arzu, "Ötanazi ve Yaşam Hakkı", TBB Dergisi, 2009, S.86, s.188-203.

Boran, Bedia, "Açlık Grevi/Ölüm Orucuna Müdahale Sorunu Tıbbi ve Hukuki Yaklaşım”, Ankara Barosu Dergisi, 2007, Y. 65, S. 3, s. 96-104.

Cengiz, Serkan, "Mahpusların Açlık Grevi Ve Zorla Besleme Paradoksu Işığında Hekim Sorumluluğu”, TBB Dergisi, 2010, S.88, s.421-438.

Eren, Mustafa, "Ölüm Oruçları: Yaşamın Kutsallığı ve Direnme Hakkı İkileminde Bir Eylem Tarzı”, MSGSÜ Sosyal Bilimler Dergisi, 2017, C.1, S. 15, s.126-141.

Feinberg, Joel, "Voluntary Euthanasia and the Inalienable Right to Life", Philosophy and Public, 1978, Y.7, S.2, s.93-123.

Feyzioğlu, Metin, "Açlık Grevi", $A \ddot{U H F D, ~ 1993, ~ C . ~ 43, ~ S . ~ 1, ~ s .157-~}$ 168.

Gürcan, Ertuğrul Cenk, "Ötanazi: Yaşama Hakkı Açısından Bir Değerlendirme”, $A \ddot{U} H F D, 2011$, Y.60 S.2, s.255-280.

Katoğlu, Tuğrul, "Ceza Hukukunda Suçun Mağduru Kavramının S1nırları”, $A \ddot{U H F D, ~ 2012, ~ Y . ~ 61, ~ S .2, ~ s .657-693 . ~}$

Kılıç, Seval, "Açlık Grevi ve Açlık Grevine Müdahale”, TipHD, 2012, S.2, s. 83-101.

Kralova, Jana, "What is social death?", Contemporary Social Science, 2015, C.10, S.3, 235-248. 
Ömeroğlu, Ömer, "Avrupa İnsan Hakları Mahkemesi Kararları Işığında; Hükümlü, Tutuklu Ve Gözaltındakilerin Açlık Grevi, Ölüm Orucu Ve Müdahale Sorunu", EÜHFD, 2011, C. XV, S. 3-4, s.83-109.

Önok, Rıfat Murat, "İnsan Hakları ve Türk Ceza Hukuku Açısından, İnfaz Kurumlan ve Tutukevlerindeki Açlık Grevlerine Müdahale Etme Yükümlülüğü ve Bunun İhmalinden Doğan Sorumluluk", İKÜ Hukuk Fakültesi Dergisi, 2005, C. 4, S. 1-2, s. 135-191.

Özbek, Veli Özer/Doğan, Koray/Bacaksız, Pınar, Türk Ceza Hukuku Genel Hükümler, 10.Baskı, Seçkin, Ankara, 2019.

Özen, Muharrem/Şahin, Meral Ekici, "Ötanazi”, Ankara Barosu Dergisi, 2010, Y.68, S. 4, s.15-36.

Özgenç, İzzet, Türk Ceza Hukuku Genel Hükümler, 15. Bası, Seçkin, Ankara, 2019.

Öztürk, Bahri/Erdem, Mustafa Ruhan, Uygulamalı Ceza Hukuku ve Güvenlik Tedbirleri Hukuku, 17.Bask1, Seçkin, 2017.

Serdaroğlu, Erika Biton, “Ötanazi-Ölme Hakkı”, Marmara Üniversitesi Hukuk Fakültesi Hukuk Araştırmaları Dergisi, Cevdet Yavuz’a Armağan, 2016, C.22, S.3, s.463-491.

Sevinç, Murat, "Bir İnsan Hakları Sorunu Olarak: Açlık Grevleri”, Ankara Üniversitesi SBF Dergisi, 2002, C. 57, S. 1. s.111-135.

Soyaslan, Doğan, "Türk Hukuk Düzeni ve Açlık Grevi Yapanlara Müdahale Sorunu", Yargitay Dergisi, Temmuz 1990, C. 16, S.3, s.269-290.

Soyaslan, Doğan, Ceza Hukuku Genel Hükümler, 8.Baskı, Yetkin, Ankara, 2018.

Soyer, Ata, "Açlık Grevleri/Ölüm Oruçları, TTB ve Son Tartışmalar", Türk Tabipleri Birliği Toplum ve Hekim Dergisi, Kasım Aralık 2000, S.6.

Tanrikulu, M. Sezgin, "IHAM Kararlarında ve Türk Hukukunda Yaşam Hakkı”, TBB Dergisi, 2006, S.66, s.51-94.

Taşkın, Ahmet, "Açlık Grevleri ve Hak Arama Hürriyeti", $A \ddot{U} E H F D$, 2003, C.VII, S.3-4, s. 513-556.

Toroslu, Nevzat, Ceza Hukuku Genel Kısım, Savaş, Ankara, 2012. 
Türk Tabipleri Birliği, "Açlık Grevleri Sırasında Tibbi Etik İlkeler ve Bunun Pratik Yansımaları" Erişim adresi: https://www.ttb.org.tr/aclik_grev/ index.html. Erişim tarihi: 30.03.2021.

Wellman, Carl, "The Inalienable Right to Life and the Durable Power of Attorney", Law and Philosophy, 1995, Y.14, S. 2, s.245-269.

Zafer, Hamide, Ceza Hukuku Genel Hükümler, 7.Bası, Beta, İstanbul, 2019.

\section{AiHM Kararları}

Ada Rossi and Others v. Italy (dec.) (nos. 55185/08, 55483/08, 55516/08, 55519/08, 56010/08, 56278/08 and 58424/08), 16 December 2008 .

Balyemez / Türkiye (Başvuru no. 32495/03), 22 Aralık 2005.

Burke v. the United Kingdom ((dec.), (no. 19807/06), 11 July 2006.

Ceesay v. Austria (no.72126/14), 16 November 2017.

Ciorap v. Moldova (no.12066/02), 19 June 2007.

Cisse v. France (no.51346/99), 9 April 2002.

Glass v. the United Kingdom ((dec.) (no. 61827/00), 9 March 2004.

Haas v. Switzerland (no.31322/07), 20 January 2011.

Herczegfalvy v. Austria (no. 10533/83), 24 September 1992.

Horoz / Türkiye (Başvuru no. 1639/03), 31 Mart 2009.

Ilaşcu and Others v. Moldova and Russia (no. 48787/99), 8 July 2004.

İbrahim Ayhan Özgül / Türkiye, Kabul edilebilirlik hakkında karar, (Başvuru no.7715/02), 6 Mart 2007.

Kılıçdaroğlu v. Turkey (no.16558/18), 27 October 2020.

Koch v. Germany (no. 497/09), 19 July 2012.

Kudla v. Poland [GC], (no. 30210/96), 26 October 2000.

Lambert and Others v. France [GC], (no. 46043/14), 5 June 2015. 
Matencio v. France (no. 58749/00), 15 January 2004.

Mouisel v. France (no. 67263/01),14 November 2002.

Murat Vural / Türkiye (Başvuru no.9540/07), 21 Ekim 2014.

Mustafa Erdoğan ve diğerleri / Türkiye (Başvuru no.346/04 ve 39779/04), 27 Mayıs 2014.

Nevmerzhitsky v. Ukraine (no. 54825/00), 5 April 2005.

Oberschlick v. Austria (no. 11662/85), 23 May 1991.

Pretty v. the United Kingdom (no. 2346/02), 29 April 2002.

Sanles Sanles v. Spain (dec.) (no. 48335/99), 26 October 2000.

X v. Germany (1984) 7 EHRR 152.

\section{Diğer Mahkeme Kararları}

The Queen on the Application of Mrs Dianne Pretty (Appellant) v. Director of Public Prosecutions (Respondent) and Secretary of State for the Home Department (Interested Party), 29 November 2001, [2001] UKHL 61. 